\title{
River flooding as a driver of polygon dynamics: modern vegetation data and a millennial peat record from the Anabar River lowlands (Arctic Siberia)
}

\author{
R. Zibulski ${ }^{1}$, U. Herzschuh ${ }^{1,2}$, L. A. Pestryakova ${ }^{3}$, J. Wolter $^{1}$, S. Müller ${ }^{4}$, N. Schilling ${ }^{2}$, S. Wetterich ${ }^{1}$, \\ L. Schirrmeister ${ }^{1}$, and F. Tian ${ }^{1}$ \\ ${ }^{1}$ Alfred-Wegener-Institut Helmholtz-Zentrum für Polar- und Meeresforschung, 14473 Potsdam, Germany \\ ${ }^{2}$ University of Potsdam, Institute of Earth and Environmental Sciences, 14476 Potsdam-Golm, Germany \\ ${ }^{3}$ Northeast Federal University, Department for Geography and Biology, 677000 Yakutsk, Russia \\ ${ }^{4}$ Freie Universität, Institute of Geological Science, 12249 Berlin, Germany \\ Correspondence to: R. Zibulski (Romy.Zibulski@ awi.de)
}

Received: 31 January 2013 - Published in Biogeosciences Discuss.: 1 March 2013

Revised: 19 July 2013 - Accepted: 23 July 2013 - Published: 28 August 2013

\begin{abstract}
The spatial and temporal variability of a lowcentred polygon on the eastern floodplain area of the lower Anabar River $\left(72.070^{\circ} \mathrm{N}, 113.921^{\circ} \mathrm{E}\right.$; northern Yakutia, Siberia) has been investigated using a multi-method approach. The present-day vegetation in each square metre was analysed, revealing a community of Larix, shrubby Betula, and Salix on the polygon rim, a dominance of Carex and Andromeda polifolia in the rim-to-pond transition zone, and a predominantly monospecific Scorpidium scorpioides coverage within the pond. The total organic carbon (TOC) content, TOC / TN (total nitrogen) ratio, grain size, vascular plant macrofossils, moss remains, diatoms, and pollen were analysed for two vertical sections and a sediment core from a transect across the polygon. Radiocarbon dating indicates that the formation of the polygon started at least $1500 \mathrm{yr}$ ago; the general positions of the pond and rim have not changed since that time. Two types of pond vegetation were identified, indicating two contrasting development stages of the polygon. The first was a well-established moss association, dominated by submerged or floating Scorpidium scorpioides and/or Drepanocladus spp. and overgrown by epiphytic diatoms such as Tabellaria flocculosa and Eunotia taxa. This stage coincides temporally with a period in which the polygon was only drained by lateral subsurface water flow, as indicated by mixed grain sizes. A different moss association occurred during times of repeated river flooding (indicated by homogeneous medium-grained sand that probably
\end{abstract}

accumulated during the annual spring snowmelt), characterized by an abundance of Meesia triquetra and a dominance of benthic diatoms (e.g. Navicula vulpina), indicative of a relatively high $\mathrm{pH}$ and a high tolerance of disturbance. A comparison of the local polygon vegetation (inferred from moss and macrofossil spectra) with the regional vegetation (inferred from pollen spectra) indicated that the moss association with Scorpidium scorpioides became established during relatively favourable climatic conditions, while the association dominated by Meesia triquetra occurred during periods of harsh climatic conditions. Our study revealed a strong riverine influence (in addition to climatic influences) on polygon development and the type of peat accumulated.

\section{Introduction}

Polygon mires are the most common type of arctic mire. Often these mires occur in an advanced stage of succession, known as low-centred polygons (Minke et al., 2007). Lowcentred polygons evolve when frost-heave processes form ridges (the polygon rims) above ice wedges, and depressions between the ridges that are often water-filled (the polygon pond). Although these mires only cover about $3 \%$ of the arctic land area, they contain more than $15 \%$ of the world's soil carbon (Post et al., 1982); hence they play an important role in the arctic carbon cycle (Hobbie et al., 2002). Improving 
our understanding of polygon dynamics is therefore a key scientific objective. Due to the harsh living conditions, plants with short life cycles are common as well as those capable of asexual reproduction. Woody shrubs and herbs are consequently replaced at higher latitudes by cryptogams, as a result of their lower requirements for light, temperature, and nutrients (Frahm, 2001). Most of the biomass in the arctic tundra is therefore fixed in peat from decomposed bryophytes (Longton, 1997).

Climate and the nature of the soil substrate are the main factors influencing the formation of polygons, while their dimension, form, and position within landscapes are controlled by complex positive feedbacks between vegetation, ice, water, and peat (Minke et al., 2007). Investigations have previously been conducted into the ecology of polygonal landscapes and the way in which they function. For example, the hydrology of the active layer has been investigated in relation to the form of the polygon (Riordan et al., 2006; Yoshikawa and Hinzman, 2003) and the displacement of soil by frostheave processes (Mackay, 2000). The dependence of the energy and water balances in the polygonal tundra on precipitation and weather conditions has already been investigated (Boike et al., 2008). Investigations into the shape and sediment characteristics of river-influenced polygons in northern Russia have mainly been carried out in the Lena River delta (Boike et al., 2013; Fiedler et al., 2004). During the last decade studies have been conducted with a special focus on the carbon content (Zubrzycki et al., 2013), and on the net ecosystem $\mathrm{CO}_{2}$ exchange, for example in low-centred polygons on Samoylov Island (Runkle et al., 2013). Other investigations have used polygon sediments to trace short-term changes in vegetation (De Klerk et al., 2011) and long-term changes in landscape dynamics (Minke et al., 2009; Zoltai and Vitt, 1990, 1995). While previous studies have identified the general processes that lead to the formation of polygon mires, the polygon dynamics and associated driving factors remain only poorly understood.

In the North Siberian Lowland, polygon mires are particularly common along rivers or in the vicinity of lakes. We therefore selected an individual low-centred polygon (designated 07-SA-LY) on the flood plain of the lower Anabar River as a study site, using a multi-method approach that included analysis of vegetation, fossil moss tissue, pollen, diatoms, grain size, and organic matter, together with radiocarbon dating. The objectives of this research were (1) to investigate the spatial pattern of vegetation in relation to abiotic factors, (2) to reconstruct past changes in biotic communities and abiotic environments, and (3) to identify the drivers behind the polygon dynamics.

\section{Geographic setting}

The study area in north-western Yakutia (Siberia) is characterized by an extreme continental climate. Winters are domi- nated by a stable high pressure system over the Siberian landmass, resulting in low temperatures (mean January temperature: $-36.1{ }^{\circ} \mathrm{C}$ ) and only a thin snow cover. Summers are dominated by Icelandic and Aleutian lows; they are short and relatively cool, with mean July temperatures of $12{ }^{\circ} \mathrm{C}$ (Saskylakh Climate Station, $71.967^{\circ} \mathrm{N}, 114.083^{\circ} \mathrm{E}$; Rivas-Martinez and Rivas-Saenz, 2007).

The study area is underlain by 500 to $600 \mathrm{~m}$ of permafrost (Yershov et al., 1991). Temperature increases at the beginning of the Holocene initiated thermokarst processes that led to permafrost degradation and widespread subsidence (Czudek and Demek, 1970). The study area is characterized by meander terraces, polygon mires and in a wider surrounding thermokarst lakes and alas depressions. The uppermost parts of the soils are wet and organic-rich, and are classified as Histic Fluvisols (Jones et al., 2010).

Polygon fields in the Anabar River lowlands were observed from helicopter flights to be restricted to areas along the flanks of rivers. The studied polygon is located within a polygon field on the Anabar River floodplain, about $800 \mathrm{~m}$ to the east of the riverbank and within the curve of an abandoned meander. It lies about $15 \mathrm{~km}$ north of Saskylakh on the North Siberian Lowland, in the north-eastern part of Yakutia (Fig. 1b). The Anabar River is fed by the Bol'shaya Kuonamka and the Malaya Kuonamka rivers, which originate on the Anabar Shield. It drains into the western part of the Laptev Sea $\sim 400 \mathrm{~km}$ west of the Lena River delta and has a discharge that is highly variable, both seasonally and annually. In contrast to rivers in southern Yakutia, the Anabar River freezes to the bottom during winter, followed by a rapid increase in discharge in spring that reaches a maximum of $5000 \mathrm{~m}^{2} \mathrm{~s}^{-1}$ (data from Saskylakh station; Huh and Edmond, 1999).

The lower part the Anabar River in particular is a meandering and partly braided river system (Fig. 1b). The polygon field in which our site is located is drained by several small streams flowing into the Anabar River in summer, but can be flooded in spring. Thus the rapid melting of snow in spring as a result of the sharp increase in temperature, combined with the vicinity of the site to the large Anabar River, results in a water supply to the polygon field that is both seasonally and inter-annually variable.

Our field vegetation survey has indicated that the study site lies within an area with Larix trees up to $4 \mathrm{~m}$ high. The area belongs to the "Anabar-Lena subarctic" geobotanical sub-province (Isaev et al., 2010), described on the agriculture map of Yakutia (Matveev, 1989) as having a "widely spaced dwarf shrub tundra (Betula exilis, Salix pulchra), dwarf shrub tundra (Betula exilis, Salix pulchra together with Cetraria cucullata, Alectoria ochroleuca, Coelocaulon divergens) and tundra bog" vegetation type. 

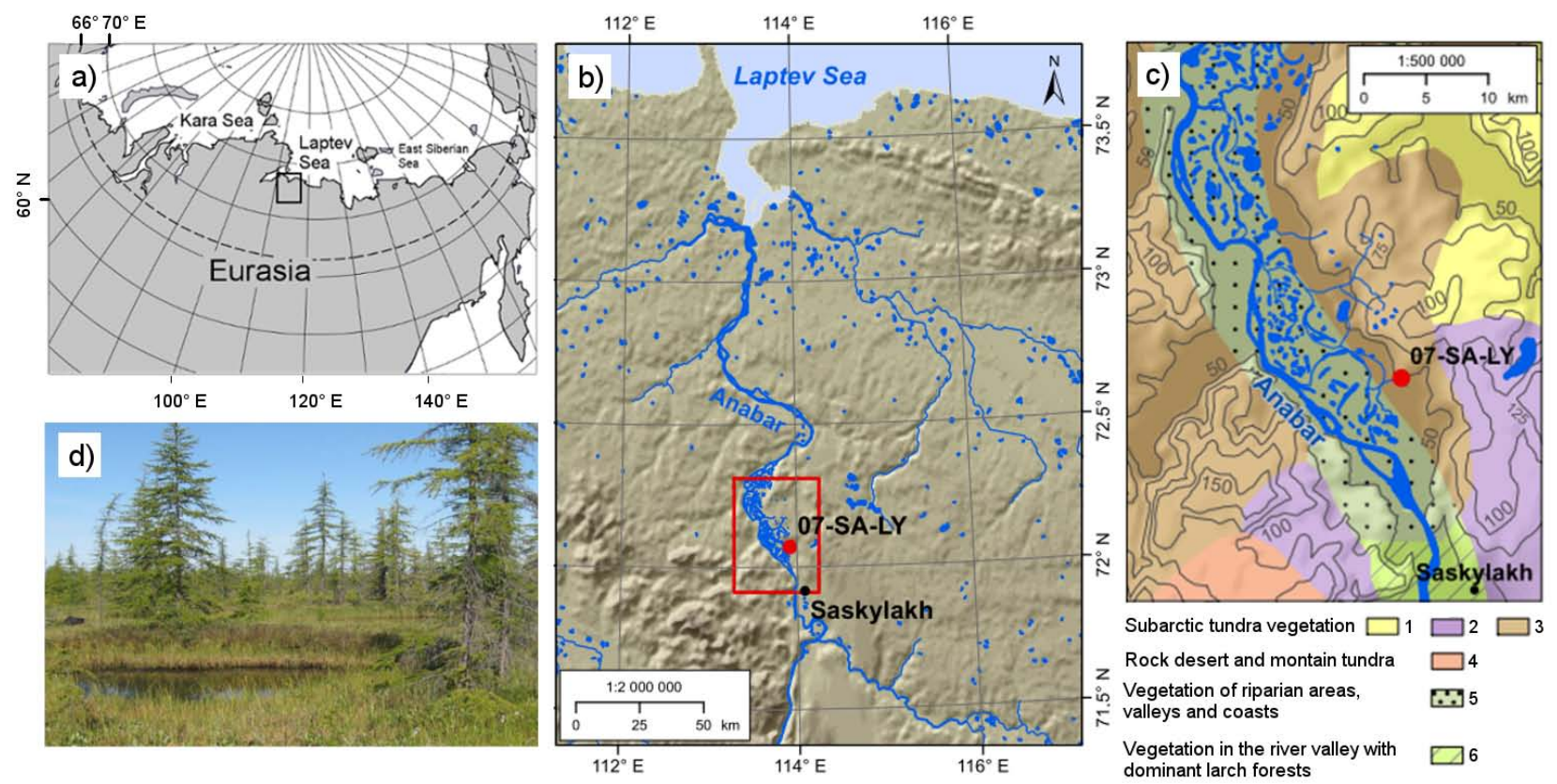

Fig. 1. Location of the study area. The studied polygon (07-SA-LY) is located south of the Taymyr Peninsula (a) and $160 \mathrm{~km}$ south of the Laptev Sea coastline in the vicinity of the Anabar River, North Siberian Lowland (b), within an abandoned meander on the river's floodplain (c). Larix is sparsely distributed throughout the area (d) and the land surface is covered with a shrub-moss community. (Photo: U. Herzschuh, August 2007).

\section{Materials and methods}

\subsection{Fieldwork}

Fieldwork was completed in August 2007. A typical lowcentred polygon $\left(07-\mathrm{SA}-\mathrm{LY} ; 72.070^{\circ} \mathrm{N}\right.$ and $113.921^{\circ} \mathrm{E}$; Fig. 1c and d) was selected for detailed study. The polygon was divided into 156 square metre plots, using a grid labelled A to $\mathrm{L}$ and 1 to $13 \mathrm{~m}$ (Fig. 2). We measured the elevation of the land surface (including the floor of the pond) relative to the water level in the pond, as well as the depth of the active layer, at the centre of each plot (method according to Donner, 2007). The coverage of the main vascular plants was recorded for each plot in modified per cent classes, according to the Braun-Blanquet floristic approach (Braun-Blanquet, 1964). Several taxa could only be recorded to genus or family level because the flowering period of most taxa was already over.

We performed $\mathrm{pH}$ and conductivity measurements in the field, for both soil and surface water, along Transect G (Fig. 2a) using a WTW Multi 350i measuring instrument. We obtained a short core (Core C) of the upper $54 \mathrm{~cm}$ of sediment from plot G8 (pond), using a simple plastic tube (Fig. 2a). The core became compressed to $27 \mathrm{~cm}$ in the plastic tube during the coring process due to the loose organic material. Sub-samples were taken from Core $\mathrm{C}$ at $1 \mathrm{~cm}$ intervals. Since we cannot assume a homogenous compression over the whole length of the core, we present the data for the $27 \mathrm{~cm}$ core length and not for the original $54 \mathrm{~cm}$ length. In plots $\mathrm{G} 1$ and $\mathrm{G} 3$, we cut vertical soil sections of $2.3 \mathrm{~cm}$ size totalling a length of $42 \mathrm{~cm}$ (Section A) and $50 \mathrm{~cm}$ (Section B). The soil samples were transported to the Alfred Wegener Institute in Potsdam, Germany, and stored at $4{ }^{\circ} \mathrm{C}$.

\subsection{Radiocarbon dating}

Hand-picked, alkali-residue plant remains from 12 sediment samples were dated by radiocarbon accelerator mass spectrometry (AMS) at the Leibniz Laboratory for Radiometric Dating and Stable Isotope Research in Kiel (Table 1), using a Tandetron 4130 AMS system (High Voltage Engineering) with a single caesium sputter ion source. CALIB rev 5.01 software modified with the IntCal04 dataset (Reimer et al., 2004) was used to calculate the calibrated ages.

\subsection{Geochemical, stable carbon isotope, and granulometric analyses}

Total carbon (TC), total organic carbon (TOC), and total nitrogen (TN) contents were measured using an elemental analyser (Elementar Vario EL III). The TOC content was measured on carbonate-free samples (treated with $4 \% \mathrm{HCl}$ ). The $\mathrm{TC}, \mathrm{TOC}$, and TN results are given as weight per cent (wt \%), and the $\mathrm{C} / \mathrm{N}$ ratio is expressed as TOC/TN.

Stable carbon isotope ratios $\left(\delta^{13} \mathrm{C}\right)$ in TOC were measured with a Finnigan DELTA $S$ mass spectrometer coupled to a FLASH element analyser and a CONFLO III gas mix system. 
Table 1. Summary list of determined diatom taxa (Core C), with life form information.

\begin{tabular}{|c|c|c|c|}
\hline Taxon code & Taxon name & Author & Life form \\
\hline AchMin & Achnanthidium minutissimum & (Kützing) Czarnecki & Epiphytic \\
\hline AulSub & Aulacoseira subarctica & (Müller) Haworth & Planktonic \\
\hline CymInc & Cymbella incerta & (Grun.) Cleve & Epiphytic \\
\hline Cym & Cymbella spp. & & Epiphytic \\
\hline CymTyn & Cymbella tynnii & Krammer & Epiphytic \\
\hline CymCes & Encyonema cesatii & (Rabenh.) Grun.ex A.S. & Epiphytic \\
\hline EunArc & Eunotia arcus & Ehr. & Epiphytic \\
\hline EunBil & Eunotia bilunaris & (Ehr.) Mills. & Epiphytic \\
\hline EunLun & Eunotia lunaris & Brevisson & Epiphytic \\
\hline EunMin & Eunotia minor & (Kutz.) Grun. & Epiphytic \\
\hline EunPec & Eunotia pectinalis & (Dillw.) Rabenh. & Epiphytic \\
\hline EunPra & Eunotia praerupta & Ehr. & Epiphytic \\
\hline EunSp. & Eunotia spp. & & Epiphytic \\
\hline GomGra & Gomphonema gracile & Ehr. & Epiphytic \\
\hline GomLag & Gomphonema lagerheimii & Cleve & Epiphytic \\
\hline GomSut & Gomphonema subtile & Ehr. & Epiphytic \\
\hline HanAmp & Hantzschia amphioxys & (Ehr.) Grun. & Benthic \\
\hline HanElo & Hantzschia elongata & (Hantzsch.) Grun. & Benthic \\
\hline HanSp. & Hantzschia spp. & & Benthic \\
\hline NavRhy & Navicula rhynchocephala & Kützing & Benthic \\
\hline NavLan & Navicula trivialis & Lange-Bertalot & Benthic \\
\hline NavVul & Navicula vulpina & Kützing & Benthic \\
\hline NeiIri & Neidium iridis & (Ehr.) Cleve & Benthic \\
\hline PinBrc & Pinnularia brevicostata & Cleve & Benthic \\
\hline PinMic & Pinnularia microstauron & (Ehr.) $\mathrm{Cl}$. & Benthic \\
\hline SelPup & Sellaphora pupula & Kutz. & Benthic \\
\hline StaAgr & Stauroneis agrestis & Peterson & Benthic \\
\hline StaAncGr & Stauroneis anceps f.gracilis & Rabh. & Benthic \\
\hline StaPho & Stauroneis phoenicenteron & (Nitzsch.) Ehr. & Benthic \\
\hline StaSp. & Stauroneis spp. & & Benthic \\
\hline SteMin & Stephanodiscus minutulus & (Kütz.) Cleve et Möller & Planktonic \\
\hline SteSp. & Stephanodiscus spp. & & Planktonic \\
\hline TabFen & Tabellaria fenestrata & (Lungb.) Kutz. & Planktonic \\
\hline TabFlo & Tabellaria flocculosa & (Roth.) Kutz. & Epiphytic \\
\hline
\end{tabular}

The analyses were accurate to $\pm 0.2 \%$. The $\delta^{13} \mathrm{C}$ values are expressed in delta per mil notation $(\delta, \%$ ) relative to the $\mathrm{Vi}$ enna Pee Dee Belemnite (VPDB) standard.

Grain-size distribution analyses (for grain sizes between 0.375 and $1000 \mu \mathrm{m}$ ) were conducted on freeze-dried carbonate-free (treated with $10 \% \mathrm{CH}_{3} \mathrm{COOH}$ for $12 \mathrm{~h}$ ) and organic-free (treated with $3 \% \mathrm{H}_{2} \mathrm{O}_{2}$ for a maximum of 4 weeks) subsamples from Section A, Section B (excluding the sample from 9.2 to $6.9 \mathrm{~cm}$ ), and Core $\mathrm{C}$, using a laser diffraction particle sizer (Beckman Coulter LS 200). Grainsize fractions are given in volume per cent (vol \%).

An endmember modelling algorithm (EMMA) was used to determine the origin of individual grain-size fractions and to calculate robust endmembers (EMs) from the total set of grain-size distributions with MATLAB software (R2012a; 7.14.0.739), using conceptual modifications proposed by Weltje (1997). In our study, the robust EMs and the residual member were obtained based on the 16 runs (with numbers of EMs between 3 and 6, and 4 different weight transformations). A detailed description of the EMMA method applied can be found in Dietze et al. (2012).

\subsection{Analyses of moss remains and vascular plant macrofossils}

Moss remains were analysed for every second sample from Core $\mathrm{C}$ (available volume of sieving residue after the $\mathrm{KOH}$ washing step for pollen preparation: 5-12 mL), the upper and the lower samples from Section A $(50 \mathrm{~mL})$, and 15 irregularly distributed samples from Section B $(50 \mathrm{~mL})$. The material was washed through 250 and $850 \mu \mathrm{m}$ mesh sizes. Moss remains larger than $850 \mu \mathrm{m}$ were analysed using ZEISS light and stereo microscopes (AxioLab 40, Stemi 2000-C) with $25 \times, 100 \times$, and $400 \times$ magnification; vascular plants were separated from mosses in order to evaluate their relative proportions. The identification of mosses was based on 


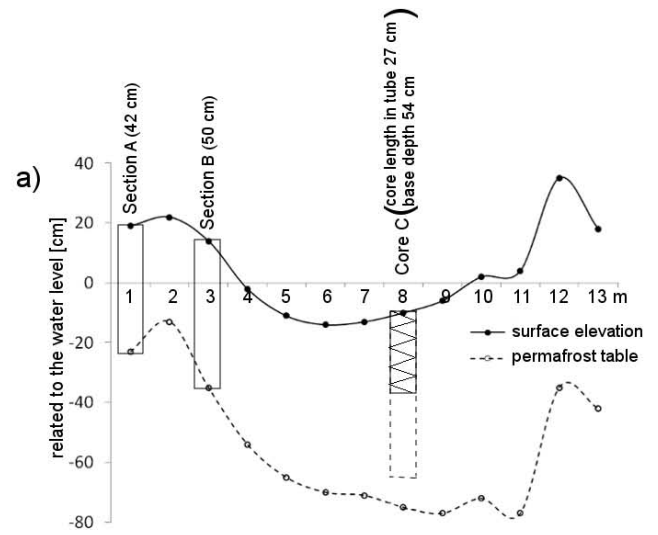

b)
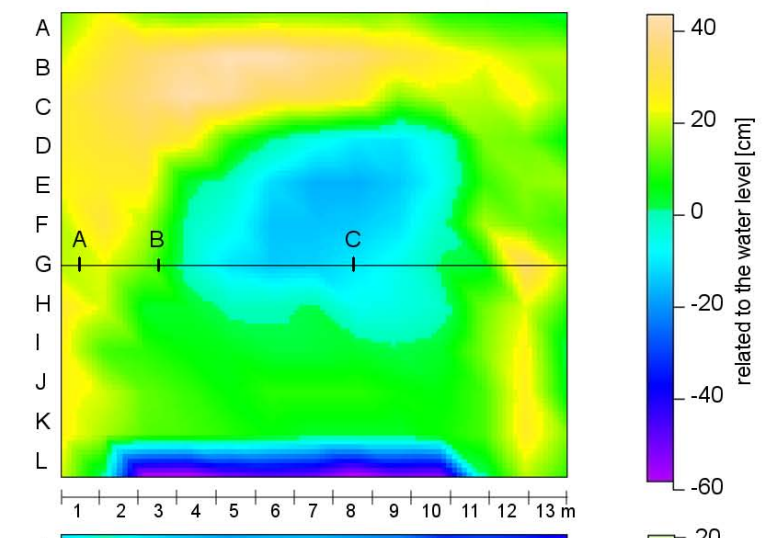

c)

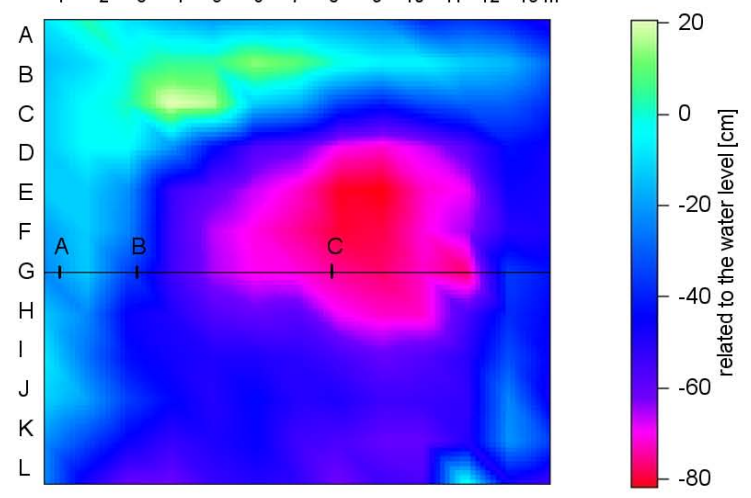

Fig. 2. The 07-SA-LY polygon was divided into a $12 \mathrm{~m}$ (A-L) by $13 \mathrm{~m}$ (1-13) grid of square metre plots. A surface transect, from which all three profiles were taken, was positioned in the grid along line G. (a) Surface elevation and thaw depth relative to the water level in the polygon pond along the surface transect (Transect G), illustrating the differences between a shallow thawing depth below the rims, in contrast to conditions beneath the pond. (Note: Core $\mathrm{C}$ was highly compressed, being reduced from 54 to $27 \mathrm{~cm}$ during sampling.) (b) The elevation of the ground surface, relative to the water level in the pond. (c) The elevation of the permafrost table, relative to the water level in the pond.

the relevant literature (Frahm and Frey, 2004; Lobin et al., 1995) and descriptions from the Bryophyte Flora of North America website (http://www.mobot.org). Amblystegiaceae taxa were not differentiated in detail in Section B.
Vascular plant macrofossils were extracted from all depths in sections A and B by washing $25 \mathrm{ml}$ subsamples through sieves with the same mesh sizes as used for mosses. Material in the +850 and $850-250 \mu \mathrm{m}$ fractions was again analysed using ZEISS light and stereo microscopes (AxioLab 40, Stemi 2000-C) and identified with the help of vegetation atlases and seed identification manuals (Anderberg, 1994; Beijerinck, 1947; Berggren, 1969, 1981; Katz et al., 1965), together with a regional reference collection at AWI Potsdam.

\subsection{Pollen analysis}

Pollen analyses were performed on all 27 samples from Core C. Processing of pollen samples in the laboratory included treatment with $\mathrm{HCl}(10 \%), \mathrm{KOH}(10 \%)$, and $\mathrm{HF}(50 \% ; 2 \mathrm{~h}$ boiling), followed by acetolysis, sieving $(7 \mu \mathrm{m})$ in an ultrasonic bath, and mounting in glycerine. At least 350 terrestrial pollen grains were counted in all except three samples (from 20 to $17 \mathrm{~cm}$ ) which had extremely low pollen concentrations. Pollen identifications were based on the relevant literature (Beug, 2004; Moore et al., 1991), and on a regional type slide collection of pollen types. The total pollen from arboreal and terrestrial non-arboreal taxa (excluding Cyperaceae) identified in each pollen spectrum is taken as $100 \%$ for the calculation of the pollen percentages. In addition, common non-pollen palynomorphs (NPPs, e.g. Pediastrum, Botryococcus, Delitschia, Gelasinospora, Gaeumannomyces, Glomus, Macrobiotus hufelandi, and Sordariales) were counted from the pollen slides and their abundances expressed relative to the total terrestrial pollen.

\subsection{Diatom analysis}

About $0.5 \mathrm{~g}$ of each sample from Core $\mathrm{C}$ was used for diatom analysis. The processing of diatoms was conducted in accordance with Pestryakova et al. (2012): the calcareous and organic components were removed by heating with $\mathrm{HCl}(10 \%)$ and $\mathrm{H}_{2} \mathrm{O}_{2}(30 \%)$. Cleaned diatom samples were mounted on microscope slides with Naphrax ${ }^{\circledR}$. About 500 diatom valves were counted per slide, along random transects. Samples were analysed using a ZEISS light microscope (AxioScope.A1) equipped with a differential interference contrast, at a magnification of $1000 \times$. The following literature was used for the determination of diatom taxa: Krammer and Lange-Bertalot (1986), Lange-Bertalot (1993), LangeBertalot and Metzeltin (1996), Lange-Bertalot et al. (1996), and Lange-Bertalot and Genkal (1999). The following regional works were also consulted: Komarenko and Vasilyeva (1975), "The diatoms of the USSR" $(1974,1988,1992)$, "The diatoms of Russia" (2003), and Loseva (2000). The classification of diatom species used in this paper is based on the latest revisions of the Achnanthes, Fragilaria, Navicula and Cymbella genera (Krammer, 2000, 2002, 2003; LangeBertalot, 2001). 


\subsection{Statistical analysis}

Statistical analyses were performed to deduce patterns in surface vegetation and in the diatom assemblages of Core $\mathrm{C}$. We applied a non-metric multidimensional scaling (NMDS) analysis of species percentages using the Bray-Curtis dissimilarity index, implemented in $\mathrm{R}$ version 2.15.0 (R Project for Statistical Computing, using the "vegan" package (Oksanen et al., 2007)). Various supplementary parameters were added to the NMDS plots.

\section{Results}

\subsection{High-resolution spatial characteristics of the investigated polygon and its vegetation pattern}

The 07-SA-LY low-centred polygon has dimensions of about $12 \mathrm{~m} \times 13 \mathrm{~m}$ (Fig. 2b). The outer margin of the investigated polygon approximately traces the ice cracks and separated it from its neighbouring polygons. The distance from the crack to the rim margin is $3-4 \mathrm{~m}$. The polygon centre is filled by an intrapolygonal pond of water with approximate dimensions of $5 \mathrm{~m} \times 7 \mathrm{~m}$. The ground surface measurements indicated that the polygon is not hydrologically closed. Transects A to $\mathrm{C}$ are up to $44 \mathrm{~cm}$ above the water level in the pond, in contrast to transects $\mathrm{H}$ to $\mathrm{K}$ (plots 5 to 10 ), which cover a transition zone to a sunken crack in Transect $\mathrm{L}$ that has a depth of $62 \mathrm{~cm}$ below the water level in the pond. The maximum height of the other rims was $35 \mathrm{~cm}$, and only minor depressions within these rims were detected, e.g. from D11 to G11, and from K2 to K11 (Fig. 2b). The active layer depth ranges from $21 \mathrm{~cm}$ beneath the rims to $73 \mathrm{~cm}$ below the floor of the polygon's pond (Fig. 2c). This depth varies considerably beneath the rims but is relatively consistent beneath the waterbody (Fig. 2c). In general, the elevation correlated well with the active layer depth $\left(r^{2}=0.81\right)$. Along Transect $\mathrm{G}$, the $\mathrm{pH}$ was found to be about 6.14 in the rim, 5.70 in the rim-topond transition zone, and 6.25 in the pond. The conductivity was highest on the rims (up to $84 \mu \mathrm{S} \mathrm{cm}^{-1}$ in G1) and lowest in the pond water (e.g. $16 \mu \mathrm{S} \mathrm{cm}^{-1}$ in G8).

A vegetation survey over the grid revealed differences in plant taxa between the rim, the rim-to-pond transition zone, and the pond (Fig. 3), as is clear from the NMDS analysis which yielded a stress value of $16 \%$ (Fig. 4). Axis 1 correlates well with elevation and active layer depth and arranges the polygon vegetation along a rim-to-pond transect. The composition of the rim vegetation (appearing on the left side of the biplot) is highly variable and diverse, but is always dominated by vascular plants such as the ubiquitous shrub Betula nana (which is abundant over 2/3 of the grid), the two different shrubby Salix species (Type A with maximum abundances of 20 to $40 \%$, and Type B with a mean coverage of approximately $20 \%$ in non-aqueous habitats), Dryas punctata, Ledum palustre, and Vaccinium sp. Eight
Larix gmelinii trees (with a maximum height of $4 \mathrm{~m}$ ) were recorded from the upper rim sites. The rim-to-pond transition zone (the central part of the NMDS biplot) is characterized by the appearance of Andromeda and/or Carex. Relatively dry zones situated only a few centimetres above the water level are covered by Type B Salix and Vaccinium sp., with abundances between 5 and $80 \%$. The pond vegetation (on the right side of the NMDS biplot) consists almost exclusively of the moss Scorpidium scorpioides; only in the shallowest parts is it intermixed with Carex taxa. In addition, individual plants of Pedicularis sp. appear in a small depression between the pond and the crack on Transect L.

\subsection{Geochronology and age-depth relationships}

The oldest ages (cal AD - calibrated years Anno Domini) were obtained from the bottom samples from Section A (420-539 cal AD) and Section B (417-568 cal AD) (Table 1). The calibrated ages obtained for Core $C$ range between 1213 and $1635 \mathrm{cal}$ AD, but do not show a clear age-depth relationship; at least the near surface date (from $3.5 \mathrm{~cm}$ depth) is the youngest of the geochronological record.

\subsection{General properties of the sedimentary fill}

The two sections (A and B) and the sediment core (Core C), from plots G1, G3, and G8, respectively, were analysed for their TOC content, TN content, and grain-size composition (Fig. A2 for sections A and B, Fig. 5 for Core C). The TOC values are relatively low in the lower parts of the profiles ( 0.3 to 1.3 wt. \% in sections $\mathrm{A}$ and $\mathrm{B} ; 1$ to $4 \mathrm{wt} . \%$ in Core $\mathrm{C})$, and higher in the uppermost (most recent) samples (32 to 33 wt. \% in sections A and B; 26 wt. \% in Core C). Due to the low TN contents (below the detection limit, i.e. $<0.1 \%$ ), reliable TOC / TN values are not available for the lower parts of sections $\mathrm{A}$ and $\mathrm{B}$. The TOC/TN ratios in Core $\mathrm{C}$ vary between 7 and 26. The $\delta^{13} \mathrm{C}$ values range between -30.6 and $-25.9 \%$ in Core C (Section A: -29.0 and $-26.3 \%$, Section B: -29.8 and $-25.3 \%$ ). The ratio ranges differ markedly between the profiles, and also vary within each profile (Fig. 5, Fig. A2). The grain-size composition of the polygon sediments is dominated by the fine to medium sand fraction (Fig. 5, Fig. A2). Only in the uppermost parts is silt about twice as abundant as sand. The endmember modelling identified one robust EM (EM1) and a residual member (RM; describing the remaining noise). They are presented in the loading plot (Fig. A1) together with their range of confidence, as calculated from 16 endmember models. EM1 represents $75.3 \%$ of the total variance within the original data and corresponds to a medium to coarse sand fraction $(180-720 \mu \mathrm{m}$, peaking at $\sim 270 \mu \mathrm{m})$. Considering the goodness of variable and sample fit, we found a reasonably good modelling for Section A $\left(r^{2}=0.92 \pm 0.14\right)$, Section B $\left(r^{2}=0.85 \pm 0.19\right)$, and Core $\mathrm{C}\left(r^{2}=0.89 \pm 0.21\right)$, for the robust endmember model. All profiles show obvious variations in the EM1 to 

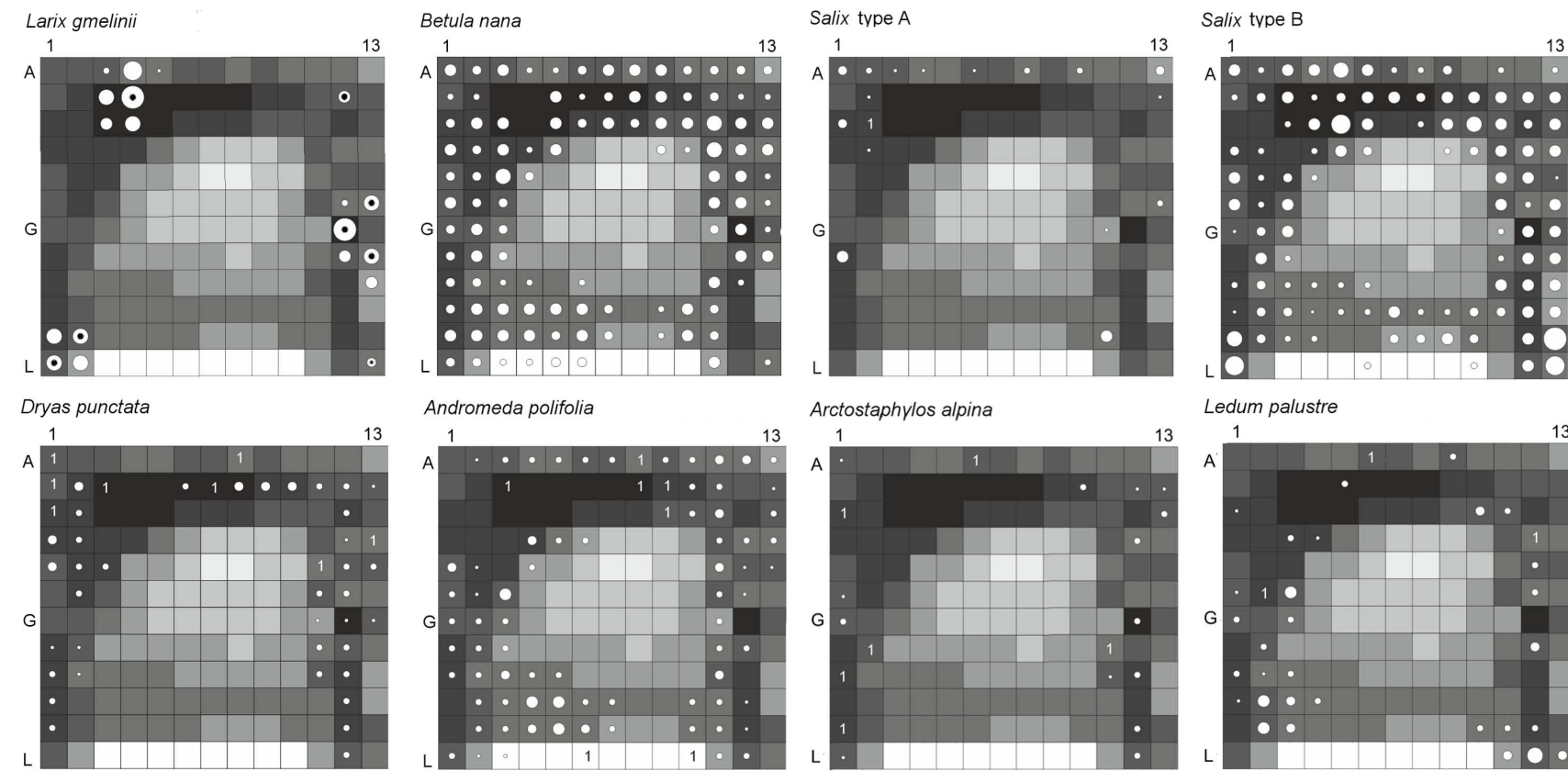

\section{Arctostaphylos alpina}

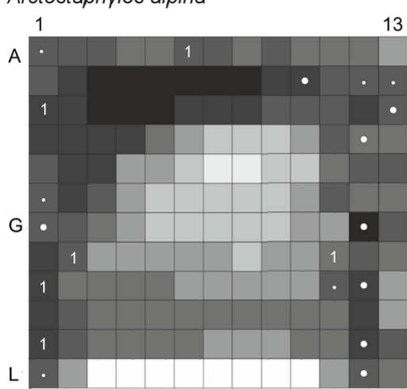

Ledum palustre
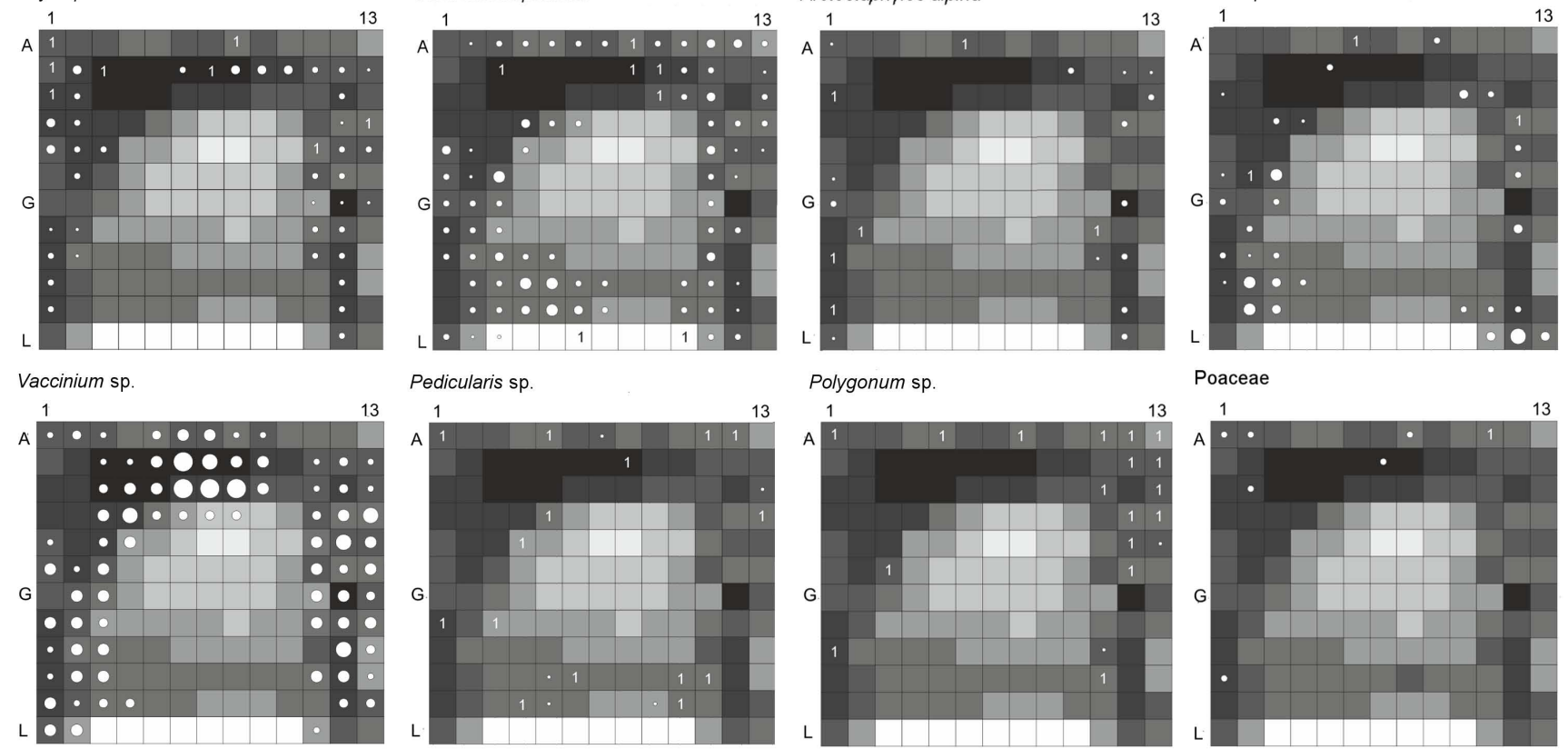

Pedicularis sp.

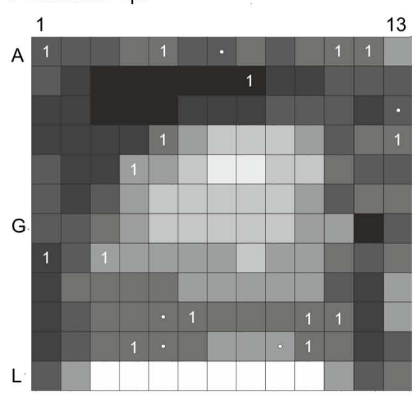

Polygonum sp.
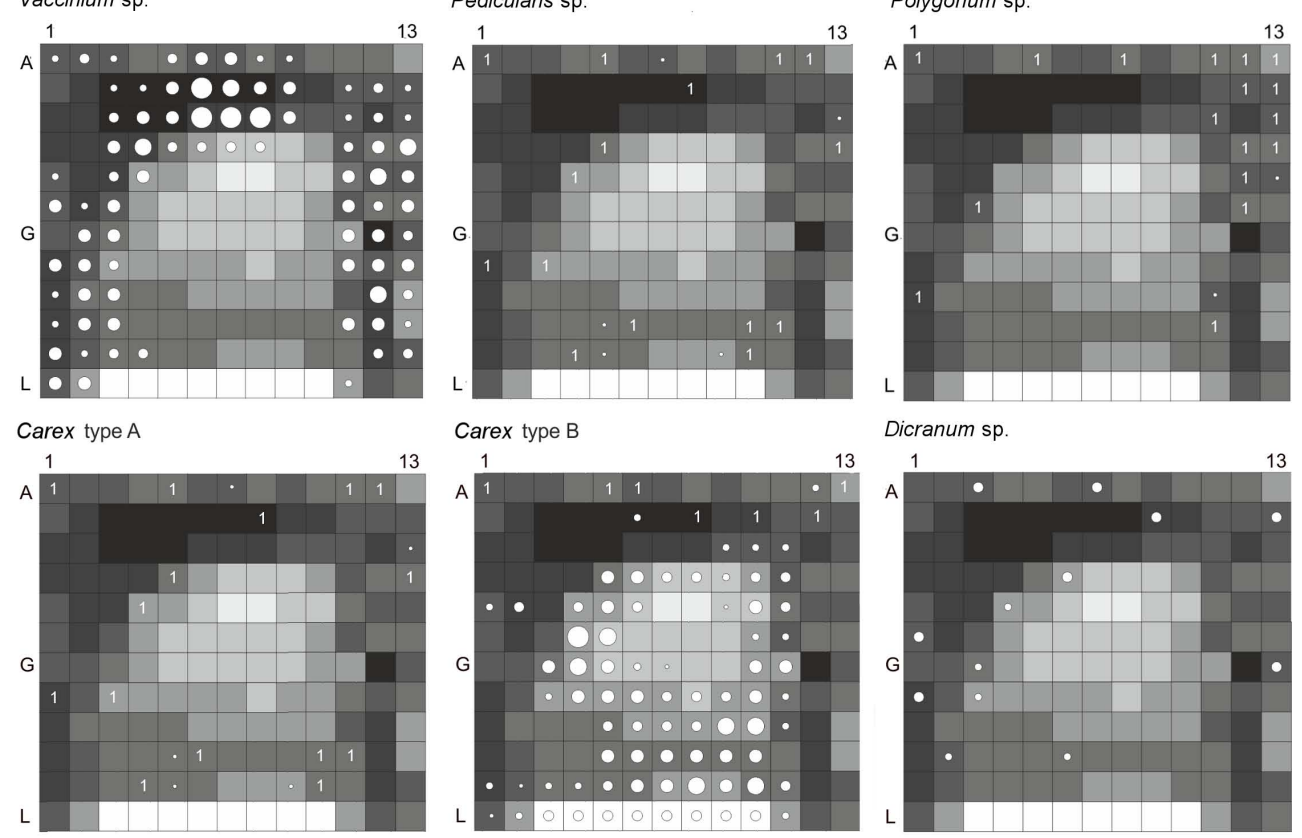

\section{Dicranum $\mathrm{sp}$}

Poaceae
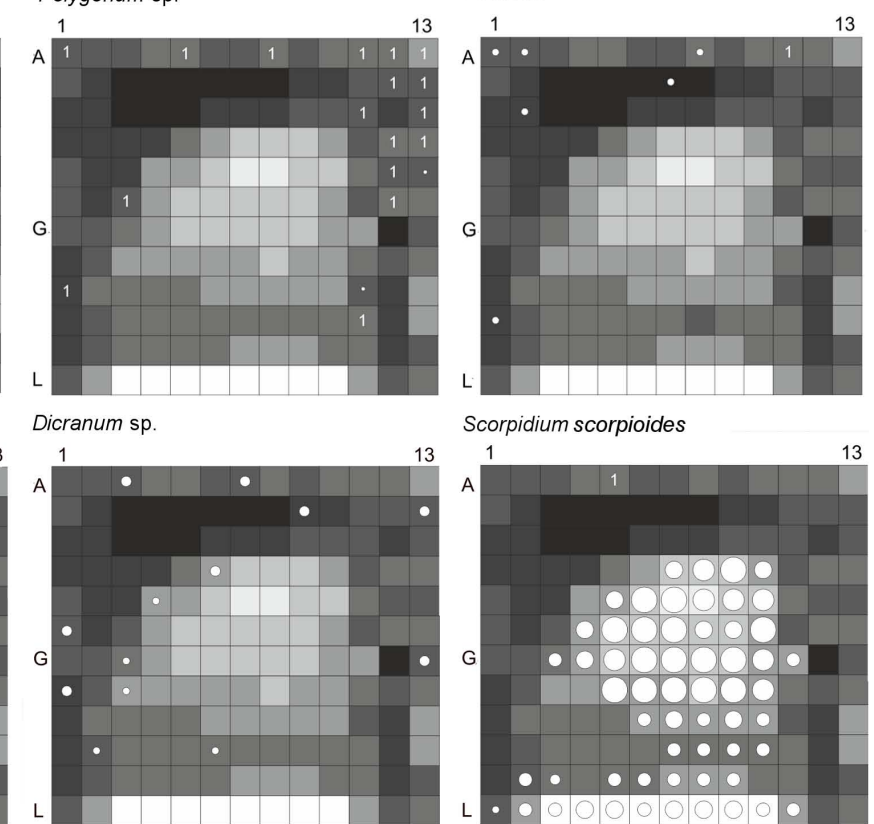

Scorpidium scorpioides

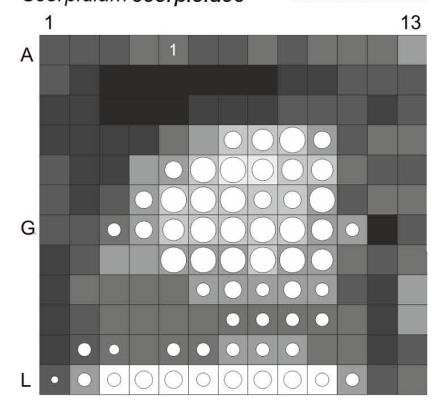

\begin{tabular}{|l|l}
$\square-62$ to $-50 \mathrm{~cm}$ & -15 to $-6 \mathrm{~cm}$ \\
-25 to $-16 \mathrm{~cm}$ & -5 to $4 \mathrm{~cm}$
\end{tabular}

elevation relative to the water leve

classification of vegetation cover
$11-2$ individuals $\circ 5-10 \%$
$20-40 \%$
$60-80 \%$
- $1-5 \%$
- $10-20 \%$
$40-60 \%$
$80-100 \%$
- location of Larix trees

Fig. 3. Distribution of plant taxa, presented in vegetation abundance/cover classes (after Braun-Blanquet, 1964) represented by circles, and related to the elevation (in cm, relative to the water level in the pond). Double circles indicate the locations of Larix trees (after Wolter, 2010). 


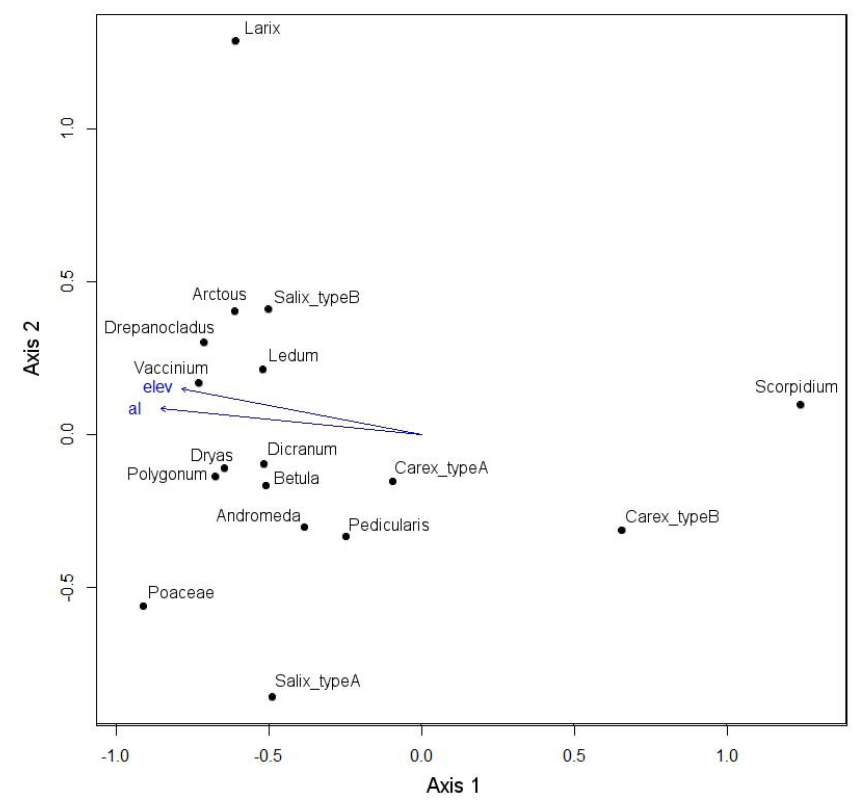

Fig. 4. NMDS plot for the surface vegetation from the 07-SA-LY polygon.

residual ratio (Fig. 5 for Core $\mathrm{C}$, and Fig. A2 for sections $\mathrm{A}$ and $\mathrm{B}$ ). Based on this information, Section B (rim-to-pond transition zone) and Core $\mathrm{C}$ (pond) can be correlated, indicating that both records cover an approximately similar period of time. In contrast, Section A shows a different sedimentation pattern and cannot be correlated with Section B, or with Core C.

\subsection{Bioindicators}

We identified 12 moss taxa within the identifiable moss leaf fraction from Core $\mathrm{C}$ (Fig. 6). Most abundant in the upper part of the core was Scorpidium scorpioides, while Meesia triquetra, Drepanocladus spp., and Hamatocaulis vernicosus were dominant in the lower part of the core. Bryum pseudotriquetrum and Rhizomnium pseudopunctatum occurred only in trace quantities. Only a single leaf of Aulacomnium turgidum was recorded (not included in Fig. 6). The vertical distribution pattern of the main moss taxa in Section B (Fig. A4) was similar to that in Core C, which supports the correlation inferred from the grain-size record. Meesia triquetra occurred in most samples from Section B and Core $\mathrm{C}$, but its abundance is highly variable. The upper parts of Section B (except for the uppermost $3.5 \mathrm{~cm}$ ) and Core C are dominated by, or entirely composed of, Scorpidium scorpioides (from 10.5 to $0 \mathrm{~cm}$ in Core $\mathrm{C}$ and from 25 to $0 \mathrm{~cm}$ depth in Section B). The moss spectrum from the rim, i.e. from Section A (Fig. A3), which was only determined in the uppermost $(1.2 \mathrm{~cm})$ and lowermost $(40.3 \mathrm{~cm})$ samples, is completely different from the spectra in Section B and Core C.

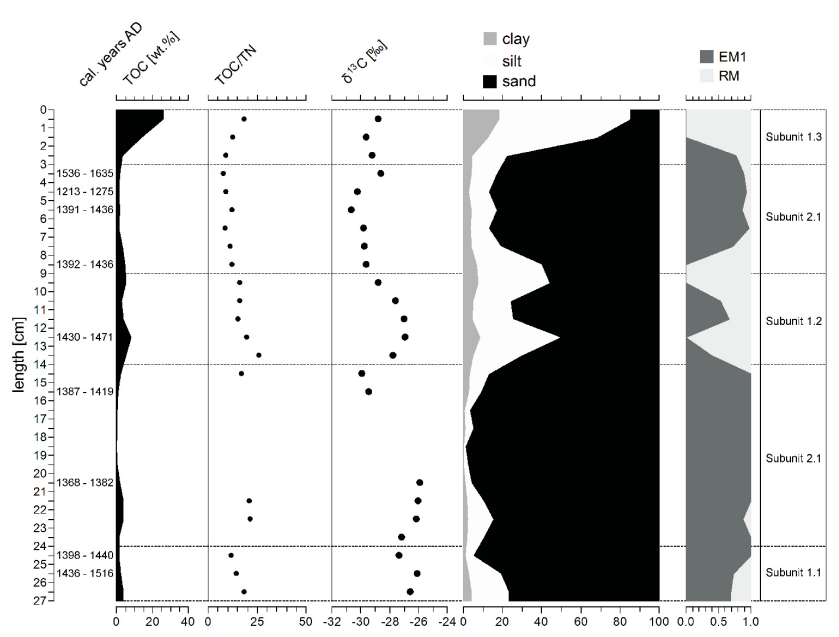

Fig. 5. Organic matter (TOC, TOC $/ \mathrm{TN}, \delta^{13} \mathrm{C}$ ) and granulometric characteristics of Core $\mathrm{C}$. The subunits present the classification of the investigated core as a result of the measured parameters.

No identifiable macrofossils were found in Core C, which may have been due to the small quantity of sediment analysed. In the upper parts of the sections A (Fig. A5) and B (Fig. A6), needles of Larix gmelinii (Section A (0.1-6.2 needles $\mathrm{cm}^{-3}$; Fig. A5) and Section B (5.719.0 needles $\mathrm{cm}^{-3}$; Fig. A6) dominate the identifiable vascular plant macrofossil spectra, while the lower part of Section B is dominated by Carex seeds $\left(0.1-1.1\right.$ seed $\left.\mathrm{cm}^{-2}\right)$. Section A contains a relatively large concentration of $\mathrm{An}$ dromeda polifolia leaves $\left(2.2\right.$ leaves $\left.\mathrm{cm}^{-3}\right)$ and Dryas punctata leaves ( 2.4 leaves $\mathrm{cm}^{-3}$ ).

The relative proportion of total vascular plant to moss remains (the VPM ratio) was examined for all samples from Section A (Fig. A3), Section B (Fig. A4), and Core C (Fig.6). Most of the samples from Core $\mathrm{C}$ were dominated by mosses, whereas the VPM ratio was relatively high at $2.5 \mathrm{~cm}(0.98)$. The ratio was slightly increased to 0.16 at $24.5 \mathrm{~cm}$ and to 0.11 at $14.5 \mathrm{~cm}$ core length. A similar pattern was found for Section B: high moss contents $(>70 \%)$ were determined for most of the lower horizons (with a short-term increase of vascular plant content to $40 \%$ at $35.7 \mathrm{~cm}$ depth), and vascular plants dominate in most samples from above $24.2 \mathrm{~cm}$ depth, with a maximum VPM ratio of 0.8 at $10.4 \mathrm{~cm}$ and $8.1 \mathrm{~cm}$ depth. Mosses became dominant again (VPM ratio 0.3) in the uppermost part of Section B (above $1.2 \mathrm{~cm}$ depth). The VPM ratios for the lowermost and uppermost samples from Section A were 0.12 and 0.17 , respectively.

Pollen analyses were performed on Core C. In total, 39 pollen taxa and 26 non-pollen palynomorphs were identified (Fig. 7). Alnus fruticosa-type, Betula nana-type and Poaceae are the most abundant pollen taxa. Betula nana-type remains quite stable throughout the core, while the abundances of Poaceae and Alnus fruticosa-type show opposing trends. Larix pollen occurs in low but stable abundances. 


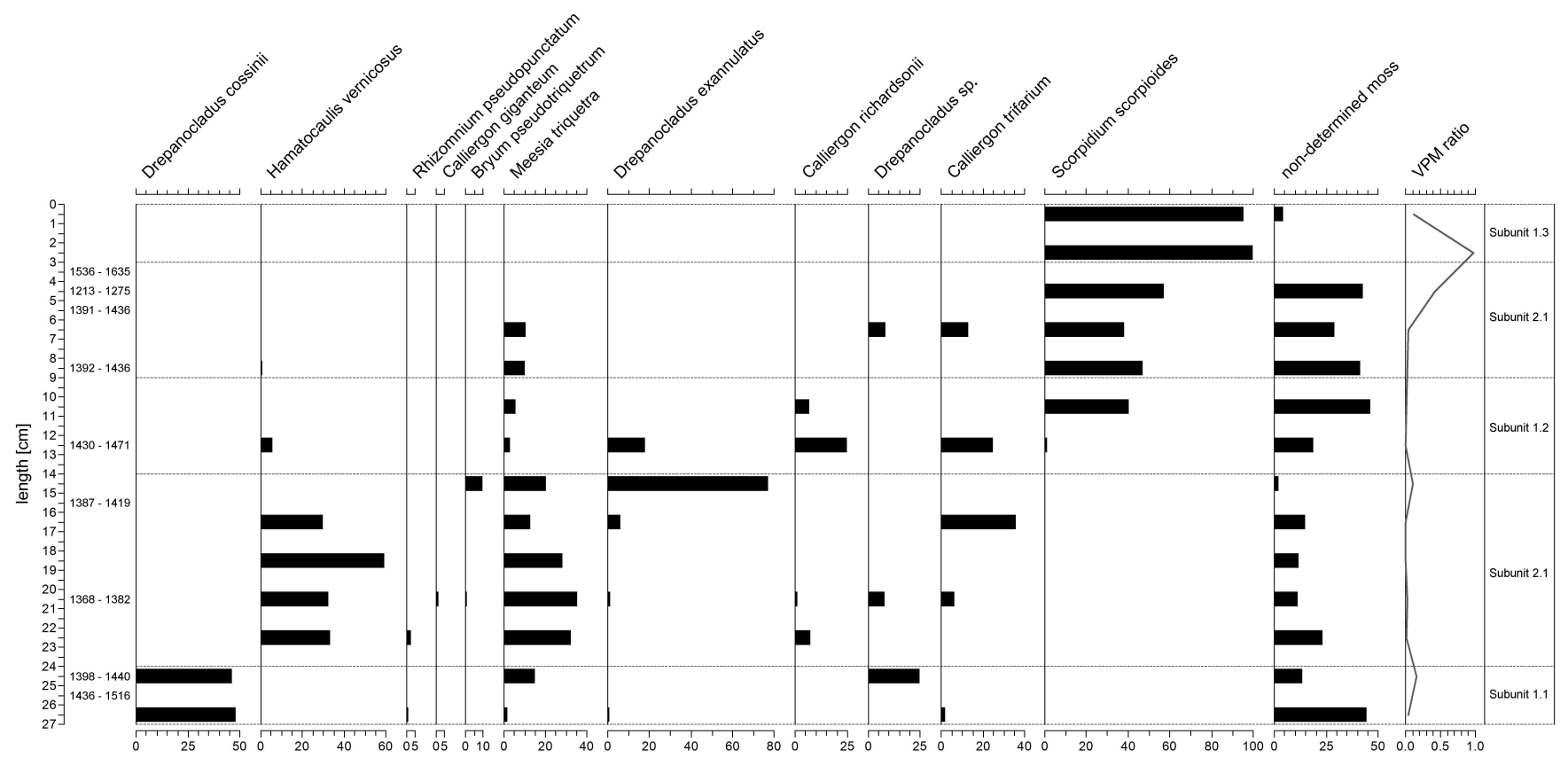

Fig. 6. The moss analyses revealed a dominance of Amblystegiaceae in Core C. The VPM ratio presents the proportion between vascular plants and mosses.

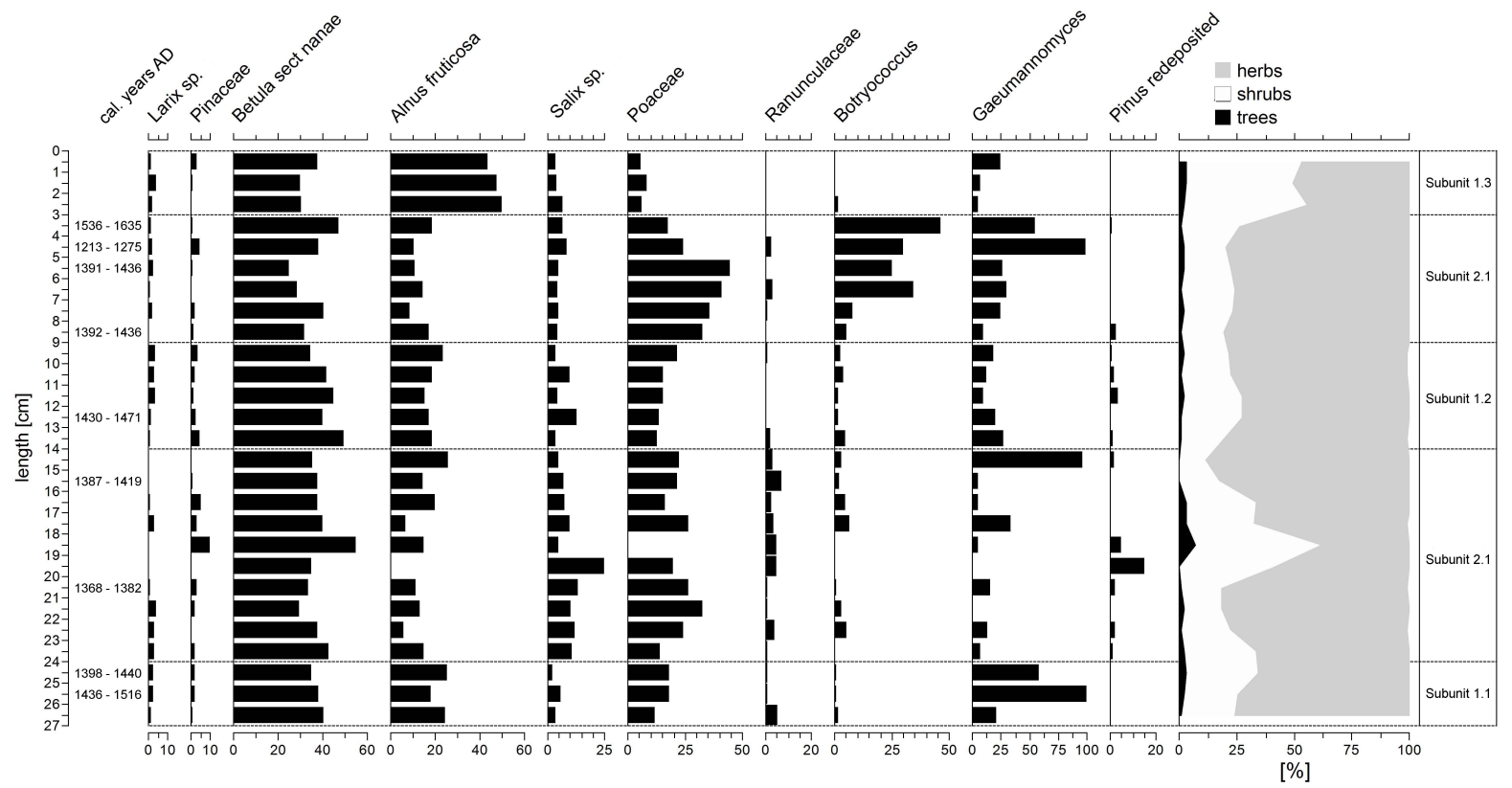

Fig. 7. Pollen percentage plot, showing the important palynomorphs and non-palynomorphs (Botryococcus and Gaeumannomyces) from Core $\mathrm{C}$. The percentages of herbs, shrubs, and trees shown in this diagram are calculated from the total pollen grain spectrum.

Except at $18.5 \mathrm{~cm}$ core length, the Cyperaceae (excluded from the pollen sum) have higher abundances than the terrestrial plants. We found relatively high quantities of the nonpollen palynomorphs Botryococcus and Gaeumannomyces.

Well-preserved diatom valves were found in all samples from Core C: 104 species were identified, belonging to 35 genera. The most important genera were Navicula (11), Eunotia (11), Pinnularia (11), Cymbella (8 species), Gomphonema (7), Fragilaria (4) and Stauroneis (4) (Fig. 8). Most genera $(63 \%$ of the total) were represented by only one or two species, which is a regional characteristic of diatom communities in arctic waters. Most of the diatom species were 


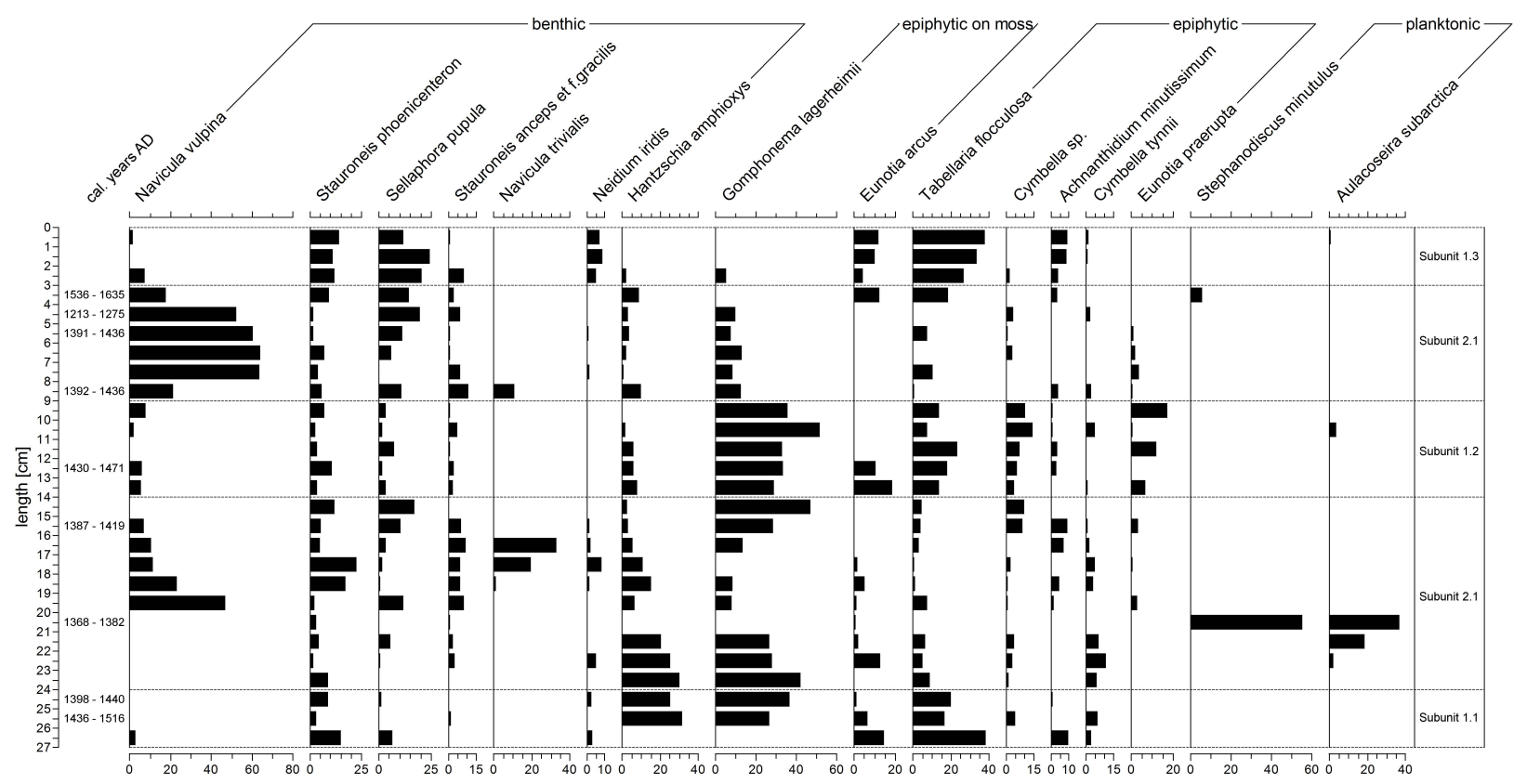

Fig. 8. Four ecological sections (benthic, epiphytic on moss, epiphytic and planktonic) showing the important species in the diatom assemblage of Core $\mathrm{C}$.

rare; thus, for the statistical analyses we only used the 32 species that met our criteria ( $>3 \%$ over the whole core). Most samples were dominated by either benthic diatoms (e.g. Navicula vulpina, Hantzschia amphioxys, Sellaphora pupula) or epiphytic diatoms (e.g. Gomphonema lagerheimii, genus Eunotia, Tabellaria flocculosa), while planktonic taxa (Aulacoseira subarctica, Stephanodiscus minutulus, Cyclotella ocellata) were only dominant at 21.5 and $20.5 \mathrm{~cm}$ length in Core C. A second peak in Stephanodiscus minutulus was found at $7 \mathrm{~cm}$ length. The NMDS analysis (NMDS plot in Fig. A7) yielded a stress value of $17 \%$. Samples from core lengths of 21.5 and $20.5 \mathrm{~cm}$ were excluded from the NMDS analysis due to their completely different diatom spectra. Most epiphytic taxa were located in the lower left part of the plot and most benthic taxa in the upper right part.

\subsection{Characterization of two different types of polygon pond sediment}

Two sedimentary units that were only found in the polygon centre (Core C) and the rim-to-pond transition zone (Section $\mathrm{B}$ ) can be distinguished on the basis of the various parameters described above, while the rim section (Section A) has a different composition. We defined the boundary between these units (Fig. 5) on the basis of the diatom NMDS analysis (Fig. A7). Meaningful sediment parameters (EMs, moss taxa, pollen taxa, non-pollen palynomorphs) were superimposed on the NMDS plot. An obvious relationship exists between diatom assemblages and these superimposed pa- rameters, indicating that the diatom spectra are related to the endmember scores and to the relative abundances of Scorpidium scorpioides, Meesia triquetra, Hamatocaulis vernicosus, the green algae Botryococcus, and the Alnus fruticosa-type pollen.

Unit 1 is characterized by high scores for the residual member (RM), which is indicated by a mixture of grain-size fractions. Unit 1 can be divided into three subunits for Core B and Section B: Subunit 1.1 (Core C, 27-24 cm core length and Section B, 50.6-43.7 cm depth), Subunit 1.2 (Core C, $14-9 \mathrm{~cm}$ core length and Section B, 27.6-16.1 cm depth), and Subunit 1.3 (Core C, $3-0 \mathrm{~cm}$ core length and Section B, 9.2$0 \mathrm{~cm}$ depth).

Both the TOC content and the TOC/ TN ratio are quite high in these units. Scorpidium, and some Drepanocladus species dominate the moss spectrum. In contrast, Meesia triquetra is only found in small quantities. Furthermore, Unit 1 is characterized by a dominance of epiphytic diatoms such as Tabellaria flocculosa, Achnanthidium minutissimum, and several Eunotia taxa (Figs. 8 and 9). Alnus fruticosa-type pollen is abundant. Despite of these common features, each subunit $(1.1,1.2$, and 1.3) has some specific characteristics that occur in both Core C and Section B. Drepanocladus cossonii is abundant in the samples from Subunit 1.1. They also contain large quantities of non-determined mosses (approximately $45 \%$ of the total moss remains), which could also belong to the Drepanocladus genus. Subunit 1.2 contains a large proportion of Scorpidium scorpioides (40\%), but low abundances of Meesia triquetra. Subunit 1.3 is dominated by Scorpidium (95-100\%) in Core C, but the 


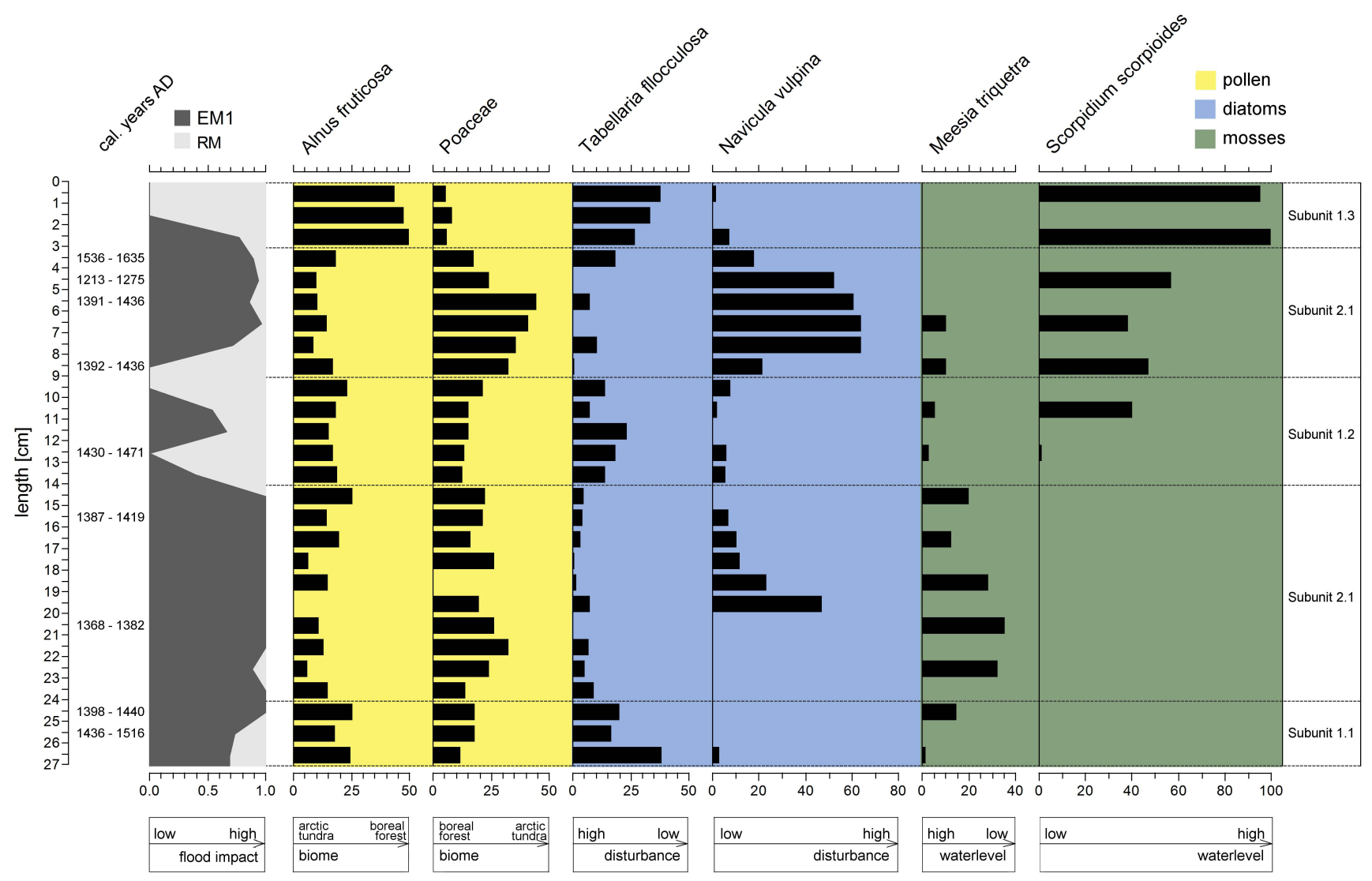

Fig. 9. Summary plot of important indicator records from Core C. The variations in endmember scores, pollen, and diatom data indicate the boundaries between Unit 1 and Unit 2, while the two moss species reflect the local hydrology in Core C.

Scorpidium content in Section B is rather low (ranging from $86 \%$ at $8 \mathrm{~cm}$, to $4 \% 1.2 \mathrm{~cm}$ ) while other Amblystegiaceae were more abundant.

Unit 2 is characterized by high scores for EM1, which is indicated by a dominance of well-sorted, medium-grained sand. Unit 2 is divided into two subunits for Core B and Section B: Subunit 2.1 (Core C, 24-14 cm length and Section B, $43.7-27.6 \mathrm{~cm}$ depth) and Subunit 2.2 (Core C, 9-3 cm length and Section B, $16.1-9.2 \mathrm{~cm}$ depth).The TOC values and TOC/TN ratio are mostly low. Meesia triquetra is present in most samples, and often abundant. Most samples are dominated by benthic diatoms (e.g. Navicula vulpina, Stauroneis phoenicenteron, Sellaphora pupula). Furthermore, Poaceae are well represented in the pollen spectra. In addition, Ranunculaceae are abundant in some sections of Unit 2. Despite of these common characteristics, subunits 2.1 and 2.2 have some specific characteristics. Subunit 2.1 contains abundant Hamatocaulis vernicosus (25-50\%), as well as abundant planktonic diatoms; it also has a low Cyperaceae content and generally a very low pollen concentration. The Botryococcus content shows a major peak in Subunit 2.2.

\section{Discussion}

\subsection{Small-scale spatial structure of polygons}

We found a strong correlation between thaw depth beneath the polygon and its surface elevation (Fig. 2a), i.e. shallow thaw depths beneath the elevated rims and greater thaw depths below the pond. It is assumed that the thick moss layer and the tall, dry vegetation on the polygon rims insulate the permafrost layer from the atmospheric temperatures (Blok et al., 2010; Luthin and Guymon, 1974). In contrast, the large thaw depth below the pond results from the high heat capacity of water - an effect that is even enhanced by the positive feedback effect from thaw water (Woo and Guan, 2006). We observed a relatively homogenous distribution of neutral to slightly acidic $\mathrm{pH}$ in the water across the polygon, which is in agreement with other studies on brown moss mires in arctic peatlands (Vanderpuye et al., 2002; Vitt, 1995; Wetterich et al., 2008).

The polygon is located in the Anabar-Lena subarctic zone (Isaev et al., 2010), with low summer temperatures and a short growing season. The present-day vegetation covering the investigated 07-SA-LY polygon (Fig. 3) is therefore dominated by typical elements of the arctic and boreal floral 
zone (Abaimov, 2010; Isaev et al., 2010; Jäger, 2005), such as Andromeda polifolia and Vaccinium sp. In these zones, sites with water-saturated soils are dominated by polygonal tundra or polygonal forest-tundra that typically show a well-developed microstructure of vegetation types tracing the hydrological microhabitats. We distinguished three different vegetation types corresponding to the dry polygon rim, the rim-to-pond transition zone, and the water-filled pond.

The vegetation on the rim contains taxa that prefer dry soils, or at least avoid permanent water saturation (Höfle et al., 2013; Matveyeva, 1994; Minke et al., 2009). We observed three layers in the vegetation community of the polygon rim: (1) a tree and shrub layer composed of Larix gmelinii, Betula nana, Salix spp., and Ericaceae such as Ledum palustre and Vaccinium sp.; (2) a dwarf-shrub and herb layer, composed of Polygonum sp., Pedicularis sp., and Ericaceae; and (3) a moss layer with xerophilous mosses (Polytrichum sp. and Dicranum sp.). The low resolution of environmental parameter measurement does not allow identification of structural parameters for the microhabitats on the rim. However, previous investigations have shown that vascular plants and bryophytes trace small-scale patterns related to the water table, thaw depth, or pH (Ellis and Rochefort, 2004; Vitt, 1995; Walker et al., 2011).

The hydrological conditions in the rim-to-pond transition zone vary markedly during the short growing season (Økland, 1990). The assemblage comprises a low dwarfshrub canopy of Betula nana, Salix type B, and Andromeda polifolia, similar to the rim vegetation but containing a higher proportion of plants that have a greater water tolerance or occur commonly in raised bogs, such as Carex. In contrast to our study, Minke et al. (2009) and Donner (2007) carried out comparable vegetation analyses in the northern Indigirka Lowland and identified Comarum palustre, Drepanocladus revolvens and Sphagnum squarrosum as common elements of vegetation in the rim-to-pond transition zone (in addition to Carex and Andromeda polifolia; de Klerk, 2008).

The water depth, and thus the position of the pond margin, depends on the water supply (e.g. from rainfall) and the evapotranspiration during summer. Since our field investigations took place in mid-August, towards the end of the arctic summer, we assume that the water level $(17 \mathrm{~cm}$ at the deepest site) was the lowest of the summer season, and that the pond at that time represented an area of permanent water (Boike et al., 2013). The transitional vegetation varies with the water depth, with Carex spp. present in the shallow parts of the pond (as also reported by Tyler, 1981). The commonly submerged moss Scorpidium scorpioides that dominates $(80-100 \%)$ vegetation within the pond belongs to the Amblystegiaceae family, which can assimilate under a thin ice cover and in low light conditions (Frahm, 2001). That special characteristic enables them to extend the short growing season and means that they are well-adapted to the harsh growing conditions in arctic polygons. The Scorpidium scorpioides community seems to represent a characteristic and widespread vegetation type as it has also been described by Liebner et al. (2011) in polygons of the Lena Delta, Donner et al. (2007) in Siberian polygons, and by Nebel and Philippi (2000) in mires of central Europe.

\subsection{Age-depth relationships}

Different ages have been inferred from different sites for when polygon mires first appeared in periglacial landscapes, sometime during the late Holocene. Botch et al. (1995) estimated that polygonal mires in the European and Western Siberian parts of the Arctic developed between 1050 and $50 \mathrm{yr}$ before $\mathrm{AD}$. Other estimates have ranged from $\sim 1650$ cal. yr before AD in Canada (Fortier and Allard, 2004) to approx. 750 cal. yr after AD for the Indigirka Lowland in Yakutia (De Klerk et al., 2011), the latter age being roughly similar to our basal age from the rim and rim-topond transition sections. However, since our samples were only collected down to the permafrost table, we cannot be sure that this is when the polygon sediments first started to accumulate. The radiocarbon dating of the basal samples indicates mean growth rates ranging between $0.27 \mathrm{~mm} \mathrm{yr}^{-1}$ (Section A) and $0.31 \mathrm{~mm} \mathrm{yr}^{-1}$ (Section B). These high sedimentation rates probably result from the dense bulk of moss, which provides a trap for minerogenic material. Furthermore, arctic mosses are known to be rapid biomass producers, according to Frahm (2001) producing up to $100 \mathrm{~g} \mathrm{~m}^{-2} \mathrm{yr}^{-1}$ depending on the local humidity. The age-depth relationship is thus rather uncertain for Core $\mathrm{C}$, which makes direct comparisons with other palaeoclimatic records impossible. The range of radiocarbon dating results is very narrow over the whole of Core C, except for those samples with a fluvial influence. Various explanations have been previously proposed for such narrow radiocarbon dating ranges: Kilian et al. (1995) suggested reservoir effects in bulk sediments as a possible explanation, whereas Price et al. (1997) found that mosses growing under wet conditions contain a proportion of recycled $\mathrm{CO}_{2}$ from older sediment layers. Our own field observations suggest that the submerged moss Scorpidium scorpioides can reach a length of several tens of centimetres down to the sediment in water-filled polygon centres. Thus some of the dated material was probably older than the layer in which it was collected, as the whole length of the moss may have been subsequently covered by sediment.

\subsection{Proxy value of the analysed parameters}

A range of biotic and non-biotic sediment properties have been investigated and have contributed in various ways and to different extents to our reconstruction of polygon development. The most relevant proxies used to summarize the development of the pond and rim-to-pond transition zone in polygon 07-SA-LY are shown in Fig. 9. Endmember scores summarize the granulometric data in a meaningful way. The modelling was applied to separate sedimentary sections that 
differ in their main sources of minerogenic material (Weltje and Prins, 2003). In our case the endmember EM1, which represents the fine to coarse sand fractions $(180-720 \mu \mathrm{m})$, probably represents the riverine transported sediment fraction. Walling and Moorehead (1989) have shown that rivers in tundra lowlands transport sediments with a mean grain size (diameter) of $150 \mu \mathrm{m}$ (fine sand) during periods of normal water levels. The larger grain sizes in our record may indicate that a proportion of the minerogenic input may have accumulated during river high stands characterized by greater sediment transportability. We assume that the RM dominated by the silt fraction has various sources other than riverine sediments imported by lateral inflow of riverine water or sediments of aeolian origin.

The general pollen composition is comparable to that of other late Holocene records from northern Siberia (Andreev et al., 2002, 2011), but is very rich in Cyperaceae compared to lake sediments (Klemm et al., 2013; Müller et al., 2010). Two pollen taxa may be used as climate proxies. We consider the percentages of Poaceae, which are typically of tundra pollen spectra (Andreev et al., 2002; Klemm et al., 2013), to indicate cold conditions. In contrast, we consider high percentages of thermophilous Alnus to be an indicator of more temperate conditions (according to Salonen et al., 2011, for northern Europe and Klemm et al., 2013, for Siberian lowlands). We assume that a large proportion of the pollen supply to the polygon originates from more distant polygons and from the wider surroundings. The pollen signal thus reflects extra-local to regional vegetation changes rather than local changes within the studied polygon. In contrast, the non-pollen palynomorphs are mainly remains of aquatic organisms and thus represent a local signal (Birks and Birks, 1980).

Diatoms are abundant in arctic freshwater systems. We observed the most marked changes in the diatom record with respect to habitat preference. As reported in other studies from Yakutia (e.g. Pestryakova et al., 2012), the spectra are dominated by cosmopolitan taxa, with minor contributions of arcto-alpine and boreal forms. The most common species found by Patrick and Reimer (1966) in Alaska, by Moore (1975) in the southern part of Baffin Island, and by Komarenko and Vasilyeva (1975), Pestryakova (2008), and Palagushkina et al. (2012) in northern Yakutia (e.g. Eunotia praerupta, Tabellaria flocculosa, Achnanthidium minutissiтит) were also identified in our polygon and, as in these other studies, our shallow waterbody was dominated by benthic and epiphytic taxa. A previous study revealed that the diatom species Tabellaria flocculosa indicates relatively stable environmental conditions, while Navicula vulpina (benthic diatom species) prefers unstable, slightly alkaline and oligotrophic phases. The proportion of Navicula vulpina was found to have increased in Unit 2.

We interpret the mosses Meesia triquetra and Scorpidium scorpioides to represent changing environmental dynamics in the water-logged polygon depression and the adjacent rim- to-pond transition zone. Scorpidium scorpioides (which is abundant in Unit 1) indicates a relatively stable pond with a steady water level, while Meesia triquetra (which is abundant in Unit 2) can grow under more unstable conditions with variable water level and prefers more terrestrial habitats than Scorpidium scorpioides (Nebel and Philippi, 2000).

The $\delta^{13} \mathrm{C}$ values from bulk organic material show similar general fluctuations to the EM1 scores and the moss record. Changes in the composition of the vegetation and source water are possible reasons for variations in the $\delta^{13} \mathrm{C}$ record. Our analyses indicated that the bulk organic material is dominated by moss remains. Mosses discriminate against heavy carbon isotopes during photosynthesis (although not as strongly as vascular plants) due to the absence of any epidermis or stomata (Farquhar et al., 1989; Peisker, 1984). A high hydrogen carbonate content in the source water, probably contributed by riverine waters, may also lead to high isotope values.

We interpret the wt \% of bulk organic material to be an indication of the minerogenic input (dilution effect) rather than of biomass productivity. However, a high minerogenic input and a temporary low water table may also have promoted oxygen infiltration and thus produced aerobic conditions, which may in turn have reduced the organic matter content due to higher decomposition rates, as is also suggested by high TOC / TN ratios (Schirrmeister et al., 2011).

\subsection{The general polygon development}

We observed marked variations in the sedimentation record of the polygon. Previous studies have shown that sediment cores from the thawed layer of polygons in arctic landscapes provide useful archives for palaeoenvironmental studies (Ellis and Rochefort, 2004; De Klerk et al., 2011). The grainsize data indicate that various sources contributed to the minerogenic input in Subunit 1.1 and that the influence of riverine flooding was low, which is supported by the relatively high TOC values and TOC/TN ratios. The vegetation was dominated by Drepanocladus cossonii, which was found by Peterson and Billings (1980) to be characteristic of wet environments; de Klerk et al. (2011), also found only sparse distributions of this species on dry rims. Thus the present-day polygon centre was a wet depression, even during the earliest recorded phase of development of the polygon. The diatom assemblage is dominated by epiphytes, and epiphytes that are specialized on moss require a particularly long ice-free period for their development (Moser et al., 2000), providing an indication that favourable growing conditions must have existed. According to Palagushkina et al. (2012), the presence of Tabellaria flocculosa indicates stable, slightly acidic environmental conditions. The lower part of Subunit 1.1 was characterized by a relatively low water level, and the upper part by a relatively high $\mathrm{pH}$. Relatively warm conditions during that period can be inferred from the high abundances of Alnus fruticosa-type. 
Repeated riverine flooding is indicated by the sandy, organic-poor sediments of Subunit 2.1. The high rate of sediment supply probably led to a turnover in the moss coverage. Apart from the floating Amblystegiaceae (Hamatocaulis vernicosus and Drepanocladus exannulatus), there is an abundance of Meesia triquetra, which is known as a pioneer species in young, post-glacial mires (Nebel and Philippi, 2000) characterized by minerogenic sediments. Furthermore, the greatest moss diversity was observed in this section, an additional indication of unstable growing conditions. Similarly, the diatom record was dominated by benthic diatoms (often cosmopolitan species with a large ecological amplitude) with preferences for disturbed (Navicula vulpina) or more aerophilic (Hantzschia amphioxys) habitats. Compared to Subunit 1.1, the diatoms in Subunit 2.1 reflect an increase in the $\mathrm{pH}$ (Dam et al., 1994), probably because the polygon's internal $\mathrm{pH}$ adjustment was repeatedly disturbed by fresh inputs of sediment and water. A sudden change to a short period of dominance of planktonic diatoms indicates that the polygon was affected by an extreme flooding event (also indicated by an input of riverine Pinus pollen), and that the water level remained high for that period of time. A study by Moser et al. (2000) showed that, in Canadian and Finnish lakes with depths of less than $5 \mathrm{~m}$, planktonic diatoms never exceeded $20 \%$ of the total diatom community. The vegetation on the polygon rim and in the uplands of the wider area surrounding the polygon contained relatively high proportions of Poaceae, which indicates cold conditions (Andreev et al., 2002). Early summer temperatures may have been decreasing at the time, resulting in reduced evapotranspiration within the polygon and an increase in the soil moisture (Seppä and Birks, 2001), which may in turn have led to a lower water absorbance capacity and eventually to more extreme flooding along the banks of the Anabar River.

The riverine sediment input was low during the accumulation of Subunit 1.2. The polygon was fully covered by moss, as indicated by both the high VPM ratio and the high proportion of specialized epiphytic diatoms growing on mossy habitats (Gomphonema lagerheimii). The diatoms indicate a shallow water level between swamp mosses. Despite of these indications of rather stable conditions within the polygon, Scorpidium scorpioides, which often prefers submerged habitats (Miller, 1980), suddenly became established in both Core $\mathrm{C}$ and Section B in the middle part of this subunit. Either the conditions within Subunit 1.2 changed from a temporarily water-filled depression to a permanently established pond, or the hydrological conditions did not change but Scorpidium scorpioides just invaded the area at that time. Favourable growing conditions can be inferred from the high proportions of Alnus fruticosa-type and Larix in the polygon rim and upland vegetation, and the reduced proportion of Poaceae.

The grain-size data indicate that riverine flooding again became more common during Subunit 2.2, but not to the same extent as in Subunit 2.1. Interestingly, organisms with mutually exclusive habitat requirements such as Navicula vulpina and Meesia triquetra (indicators of unstable and disturbed conditions), and Tabellaria flocculosa and Scorpidium scorpioides (indicators of relatively stable conditions in an established environment) co-occur in one and the same sample, which may indicate that the temporal resolution of the samples was not high enough to differentiate between individual subunits. However, the dominance of Scorpidium scorpioides (and Gomphonema lagerheimii) indicates that a permanent water-filled pond existed for at least some periods within this subunit. As was the case for Subunit 2.1, this polygon stage co-occurred with an expansion of tundra elements in the surrounding area.

The accumulation of Subunit 1.3 saw the start of conditions similar to those of the present day. The minerogenic influx is dominated by a fine silt fraction, which we assume to be a result of lateral water flow through the polygon body. A stable stage is indicated by the dominance of Tabellaria flocculosa and by the monospecific Scorpidium scorpioides vegetation occupying the permanent waterbody. A decrease in Scorpidium scorpioides toward the top of the section can be recognized in Section B, which may indicate a slight lowering of the water level as a result of either an increase in evaporation or a decrease in water influx during recent times. The vegetation in the surrounding area was characterized by the highest Alnus fruticosa-type percentages and the lowest Poaceae pollen percentages of the entire section, particularly in the upper part of Subunit 1.3, indicating the most favourable growing conditions in the entire record.

\subsection{Polygon development as a function of external controls and internal adjustment mechanisms}

The studied polygon is part of a large polygonal field and has the typical form of a low-centred polygon, with rims between the adjacent polygons (Chernov and Matveyeva, 1997; Meyer, 2003). We therefore assume that it represents a model polygon for the North Siberian Lowland and that inference concerning polygon development can, with caution, also be applied to other polygons in the same area. We hypothesize, on the basis of the spatial and temporal analyses of this polygon on the Anabar River lowlands of north-eastern Siberia, that polygon development is driven by both external controls and internal adjustment processes. Factors acting on a (supra-)regional scale such as climate, overall soil substrate, or river flooding exert pulses of external influence that disturb the dynamic equilibrium within the polygon that is otherwise maintained by local regulatory mechanisms such as plant colonization (Epstein et al., 2012; Shaver and Chapin III, 1991), moisture, summer heating and soil thawing (Peterson and Billings, 1980; Vitt, 1995; Woo and Guan, 2006), and ice wedge growth or peat accumulation (Chernov and Matveyeva, 1997). Through these internal adjustments the equilibrium in the biotope is reconfigured, and feedbacks can occur that either reduce or amplify the impact of the external 

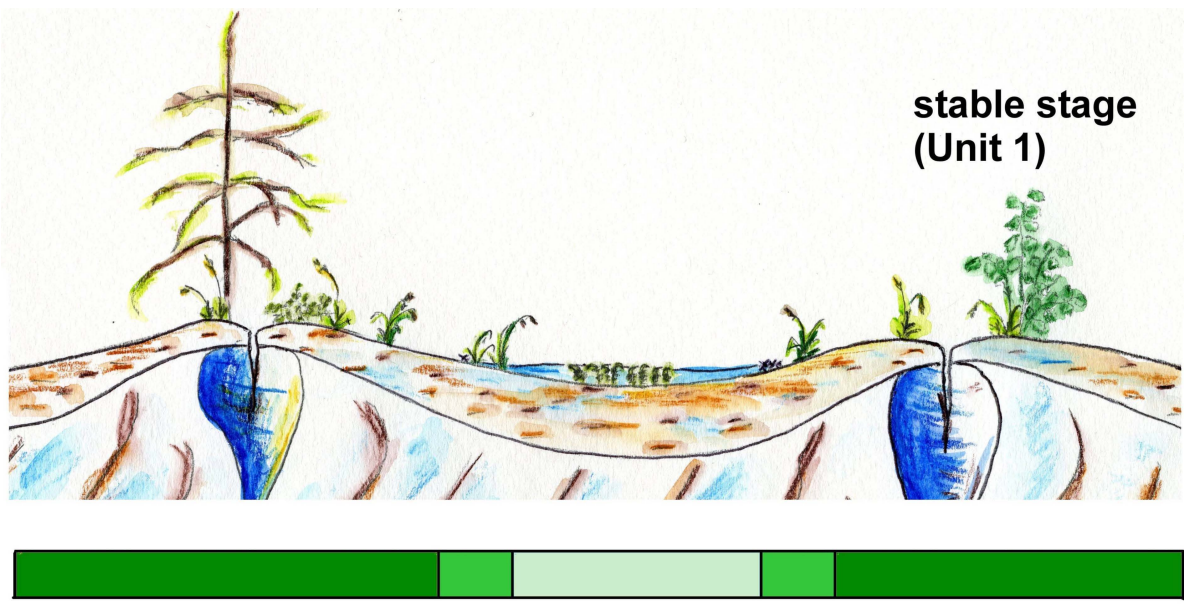

Larix gmelinii, Alnus sp., Salix spp.

Carex spp., Meesia triquetra

Scorpidium scorpioides, Tabellaria flocculosa, epiphytic diatoms

\section{unstable stage} (Unit 2)
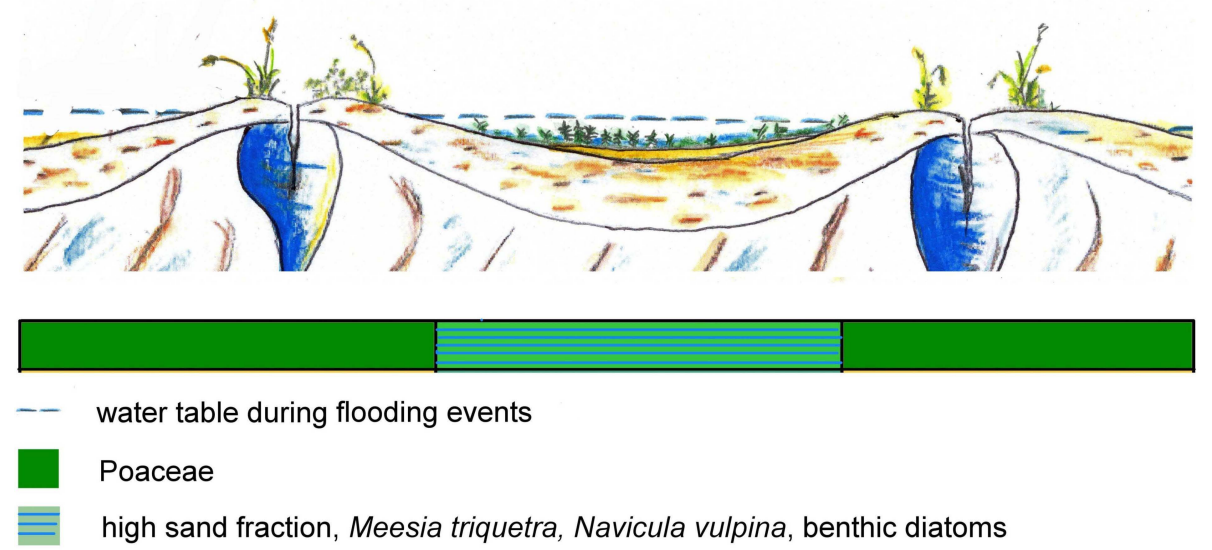

Fig. 10. Presentation showing vegetation cover during stable (Unit 1) and unstable (Unit 2) stages. For Unit 1 we detected a shrub-tussock tundra with scattered occurrences of Larix, while Unit 2 had a high proportion of sand, which affected plant communities on the rim and in the water-saturated depression (with Meesia triquetra).

controls (Harding et al., 2002; Oechel and Vourlitis, 1994). Climatic factors and a loose soil substrate may represent the primary external controls in the initiation and development of polygons. Rapidly falling temperatures in autumn lead to an increase in tensile elongation within the soil substrate, which then begins to crack (French, 2007). Meltwater or river water fills these cracks during the subsequent spring, and then freezes forming ice veins which, depending on their length, thaw during the following summer and either fill with sediment or initiate perennial ice wedges (Romanovsky, 1985). The annual growth of the wedges (approximately $1 \mathrm{~mm} \mathrm{yr}^{-1}$ : Ovenden, 1990) lifts the ambient soil substrate and forms elevated polygonal rims. As a consequence of the rim uplift, a depression then develops in the polygon centre. We interpret an initial depression stage with water-logged conditions, reflected by deposition of the first unit, followed by successive deepening of the depression during subsequent time periods (Chernov and Matveyeva, 1997).

It is assumed that the crack-initiated shape of a polygon is the result of interactions between its position within the landscape and the nature of the soil substrate (French, 2007; Minke et al., 2007). Our polygon is situated within an old meander belt of the Anabar River.

Polygons in Canada have been found to develop on sediments of various glacial and fluvial origins (Burn, 1990; Fortier and Allard, 2004). However, the original substrate for the polygon field in which our studied polygon is located probably consisted of river sands from the Anabar River, but 
these may have already had a history of soil development. Although polygons in Siberian lowlands typically occur along riverbanks, the rivers themselves have seldom been considered to be drivers of polygon development, which is what we propose for our polygon record from the Anabar River lowlands. We assume that the polygon's development was affected by slow lateral water inflow through the polygon during the accumulation of the sediments of Unit 1 (Fig. 10). In contrast, during the accumulation of Unit 2 the polygon was repeatedly flooded and the water velocity was high enough to transport medium-grained, and even coarse-grained, sand. However, the flooding would only have been seasonal as the vegetation (represented by the moss and diatom record) does not indicate a permanently high water level during the major growing season (Fig. 10). A long-term flood probably did occur during the deposition of the sediments at $20.5 \mathrm{~cm}$ core length in Core $\mathrm{C}$, which are characterized by a high planktonic diatom component. The development of the polygon was interrupted by the impact of this new control, but subsequently returned to the previous level of development. We assume that a relatively stable stage was established during the accumulation of Unit 1, as suggested by the relatively low diversity in the structure of the plant cover within the pond, the dominance of organisms with a narrow range of tolerance, the complex plant-to-plant interactions (e.g. a high number of epiphytic diatoms), and a generally high bioproductivity. In contrast, some phases during the accumulation of Unit 2 represent long-term disturbance and instability in the sedimentary succession within the low-centred polygon, initiated by repeated phases of sediment input as indicated, for example, by the large number of benthic taxa (which are often pioneer taxa) and the high diversity of mosses present (as concurrence may not yet have led to species exclusion).

Our records suggest that the controlling factors discussed above may be interdependent with regards to their timing and strength. Flooding, for example, was found to be more extreme during the colder climatic periods. Thus the response of a polygon to climate change is complex and difficult to predict. We tentatively infer from our records that higher temperatures and reduced flooding would result in the polygon communities being characterized by high moss productivity (with a high moss to minerogenic sediment ratio), a low $\mathrm{pH}$, and a specialized diatom community that is epiphytic on moss.

\section{Conclusions}

The low-centred polygon in this study is at an advanced stage of succession in space and time, with distinctive vegetation patterns. The main conclusions drawn from our research are as follows:

1. The present-day spatial vegetation patterns are closely related to abiotic factors: we observed the elevation above or below the water level to be the main controlling factor. Rim vegetation (dominated by Larix, Vaccinium, Dryas or Poaceae) can be differentiated from vegetation in the rim-to-pond transition zone (Andromeda, Pedicularis or Carex) and in the pond (comprised solely of Scorpidium scorpioides, indicating that Carex is limited by a higher water level in the pond).

2. The peat composition differs depending on the stability of the environmental conditions. Stable conditions occurred during periods with little or no riverine flooding, when submerged moss communities overgrown by epiphytic diatoms dominated the polygon centre. During times of repeated riverine flooding (indicated by medium- to coarse-grained sand within the deposits), a community became established that was adapted to instability and sediment supply (i.e. a community in which Meesia triquetra is abundant in the moss spectra, and benthic taxa in the diatom record). However, despite changes in the composition of the pond community, the general position of the pond and rim has not changed over the last $\sim 1500 \mathrm{yr}$ of recorded peat accumulation.

3. The development of polygons in flood plains is not straightforward and is influenced by the river, which may in turn be related to climatic conditions. However, various internal regulating factors within the polygon react to these changes and affect succession after such pulses of external influence, readjusting the system to a dynamic equilibrium under the new environmental conditions. 
Appendix A

Table A1. Accelerator mass spectrometry dates from polygon 07-SA-LY.

\begin{tabular}{|c|c|c|c|c|}
\hline $\begin{array}{l}\text { Section/ } \\
\text { Core }\end{array}$ & $\begin{array}{l}\text { Depth } \\
{[\mathrm{cm}]}\end{array}$ & $\begin{array}{l}\text { Radiocarbon Age } \\
{[\mathrm{yr} \mathrm{BP}]}\end{array}$ & $\begin{array}{l}\text { [cal. yr } \mathrm{AD}] \\
(2 \sigma \text { range })\end{array}$ & $\begin{array}{l}\text { Fraction } \\
\text { (C content) }\end{array}$ \\
\hline \multirow[t]{2}{*}{ Section A } & 19.6 & $426 \pm 27$ & $1426-1495$ & plant seed $(1.9 \mathrm{mg})$ \\
\hline & 40.3 & $1587 \pm 24$ & $420-539$ & plant seed, wood (2.3 mg) \\
\hline Section B & 49.5 & $1566 \pm 35$ & $417-568$ & plant seed $(0.7 \mathrm{mg})$ \\
\hline \multirow[t]{9}{*}{ Core $\mathrm{C}$} & 3.5 & $342 \pm 25$ & $1536-1635$ & mosses (Amblystegiaceae) $(0.97 \mathrm{mg})$ \\
\hline & 5.5 & $791 \pm 25$ & $1213-1275$ & mosses (Amblystegiaceae) (1.22 mg) \\
\hline & 6.5 & $544 \pm 23$ & $1391-1431$ & plants $(2.47 \mathrm{mg})$ \\
\hline & 8.5 & $535 \pm 25$ & $1392-1436$ & mosses (unidentified species) (1.1 mg) \\
\hline & 12.5 & $435 \pm 20$ & $1430-1471$ & mosses (unidentified species) ( $2.5 \mathrm{mg}$ ) \\
\hline & 15.5 & $568 \pm 23$ & $1387-1419$ & mosses (Amblystegiaceae) (2.47 mg) \\
\hline & 20.5 & $699 \pm 22$ & $1368-1382$ & mosses (Amblystegiaceae) (2.3 mg) \\
\hline & 24.5 & $518 \pm 22$ & $1398-1440$ & mosses (Amblystegiaceae) (1.53 mg) \\
\hline & 25.5 & $407 \pm 26$ & $1436-1516$ & plants $(3.5 \mathrm{mg})$ \\
\hline
\end{tabular}

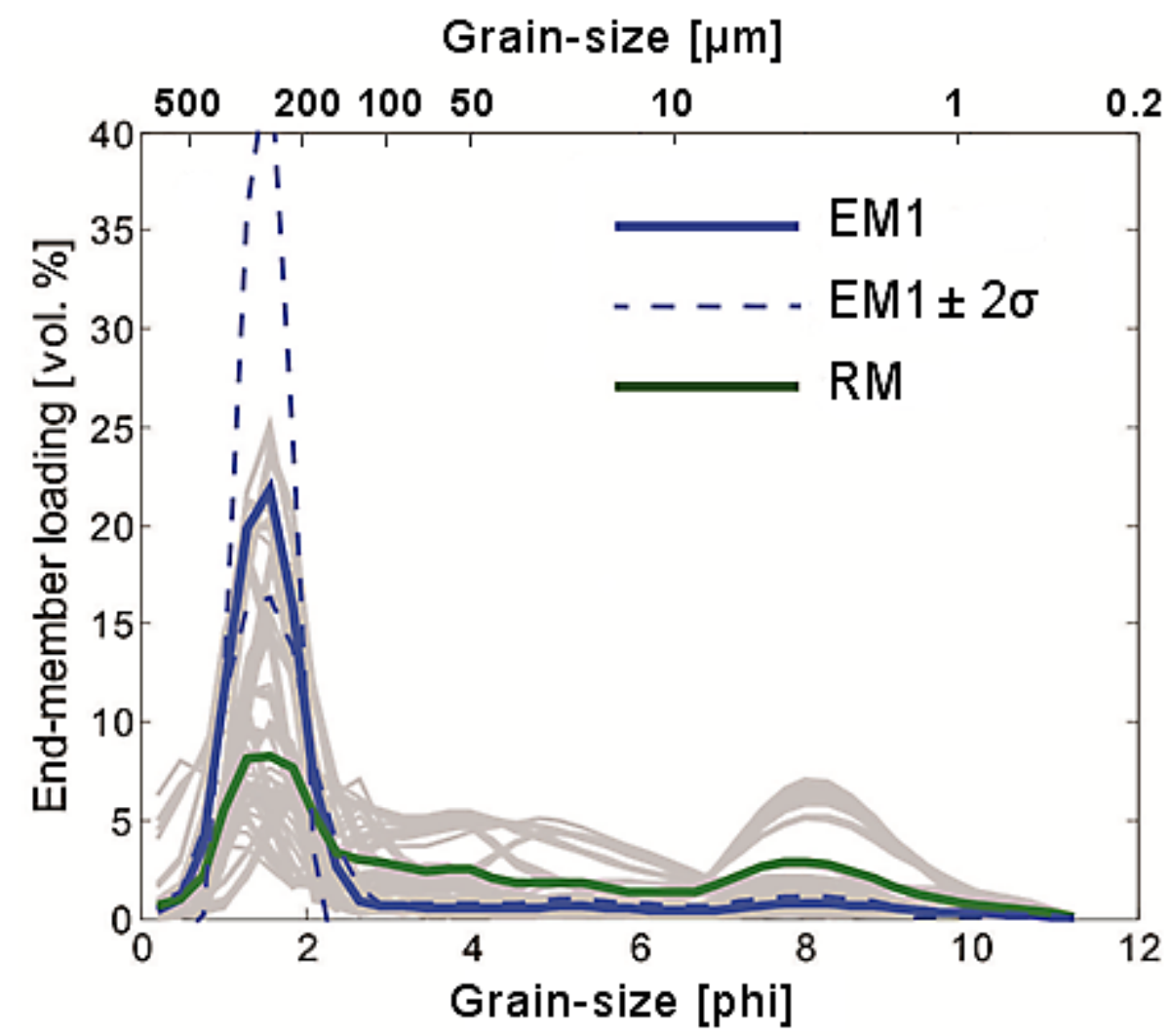

Fig. A1. Endmember loadings for samples from sections A, B and Core C represent sedimentological interpretable unmixed grain-size distributions (grey solid lines: all endmembers from the 16 endmember modelling versions). 



Fig. A2. Summary plot of organic matter (TOC, TOC / TN) and granulometric characteristics (endmember scores and grain-size distribution) from sections A and B. The granulometric parameters for Section B, $9.2 \mathrm{~cm}$ to $6.9 \mathrm{~cm}$, were not measured. 


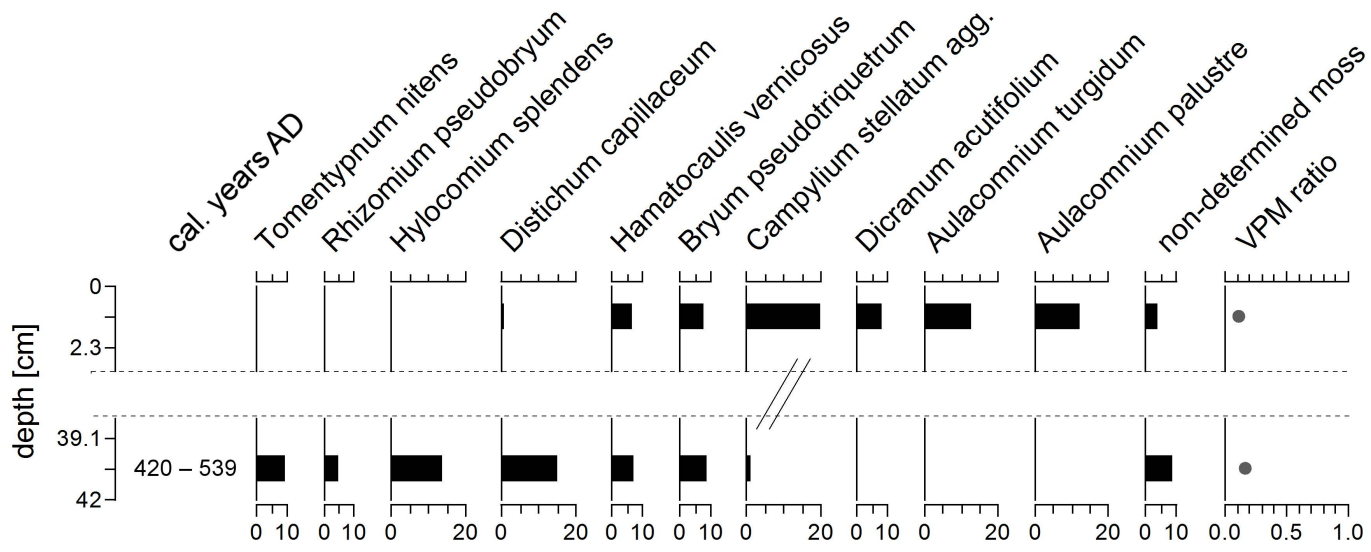

Fig. A3. Moss spectrum for Section A. Only the surface and bottom samples from this section were analysed.

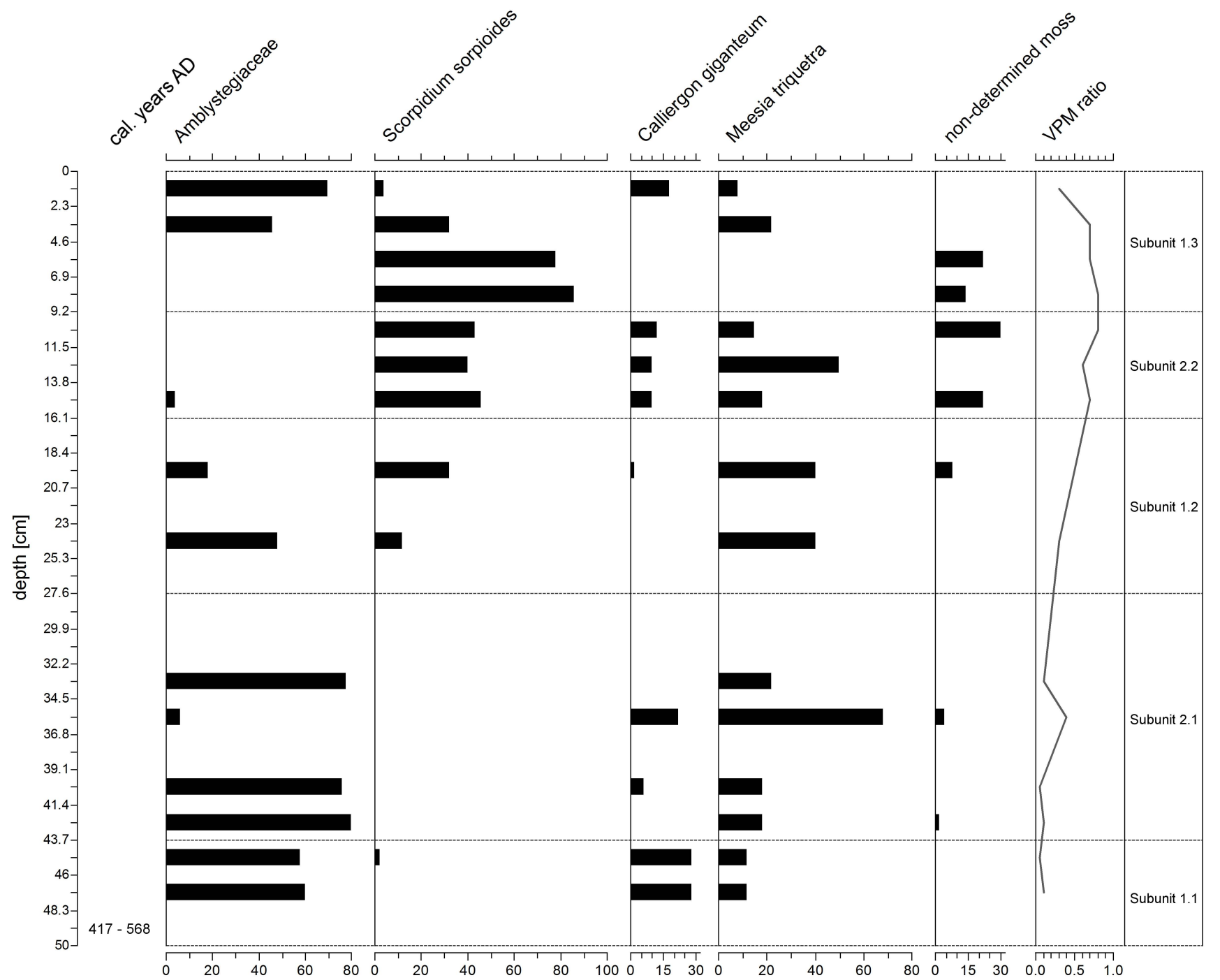

Fig. A4. Moss spectrum for Section B. The figure does not include the complete moss spectrum as only several Amblystegiaceae taxa were analysed in this section, especially Scorpidium scorpioides, Calliergon giganteum, and Meesia triquetra (after Schilling, 2012). 


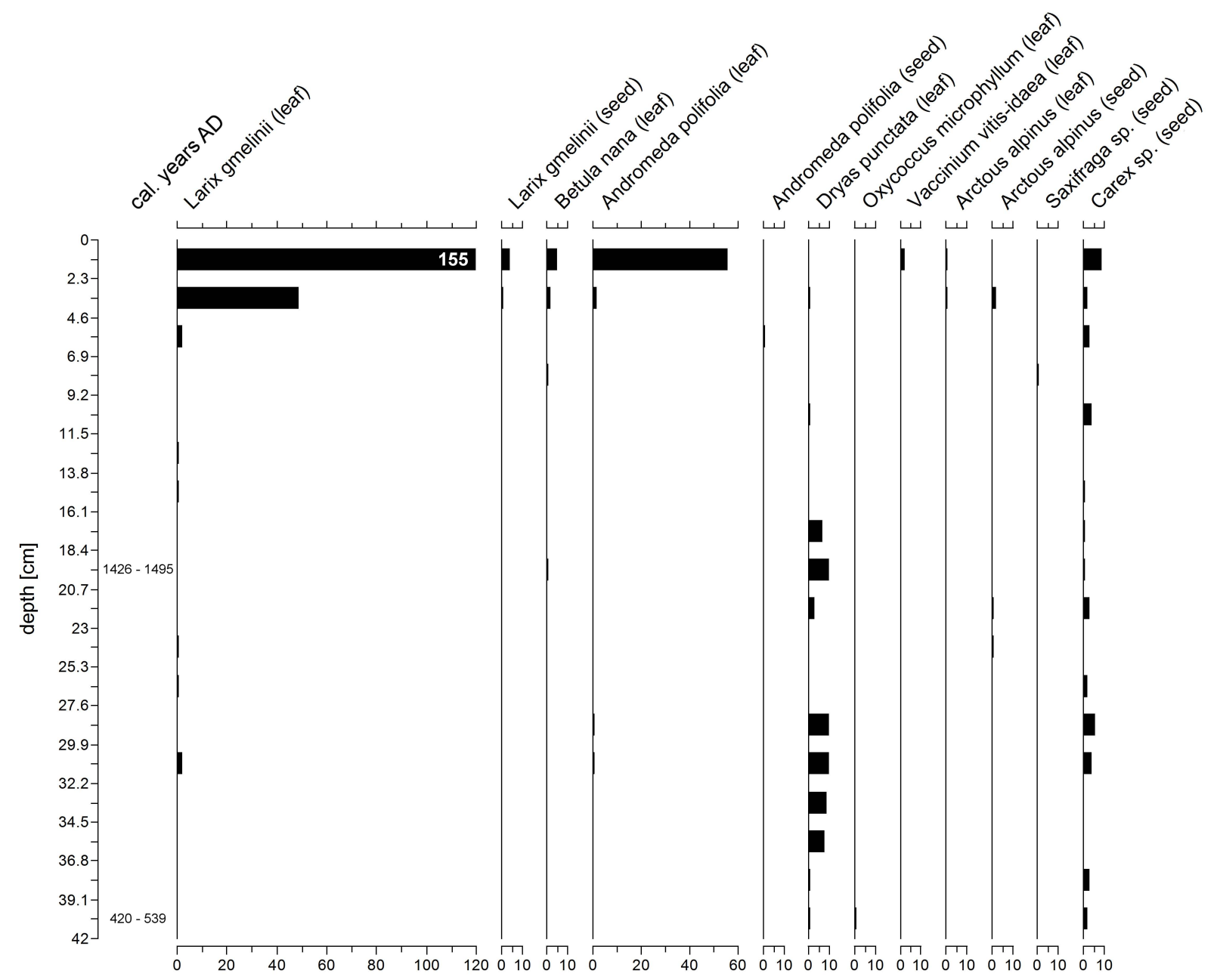

Fig. A5. Results of the macrofossil analysis for Section A. 


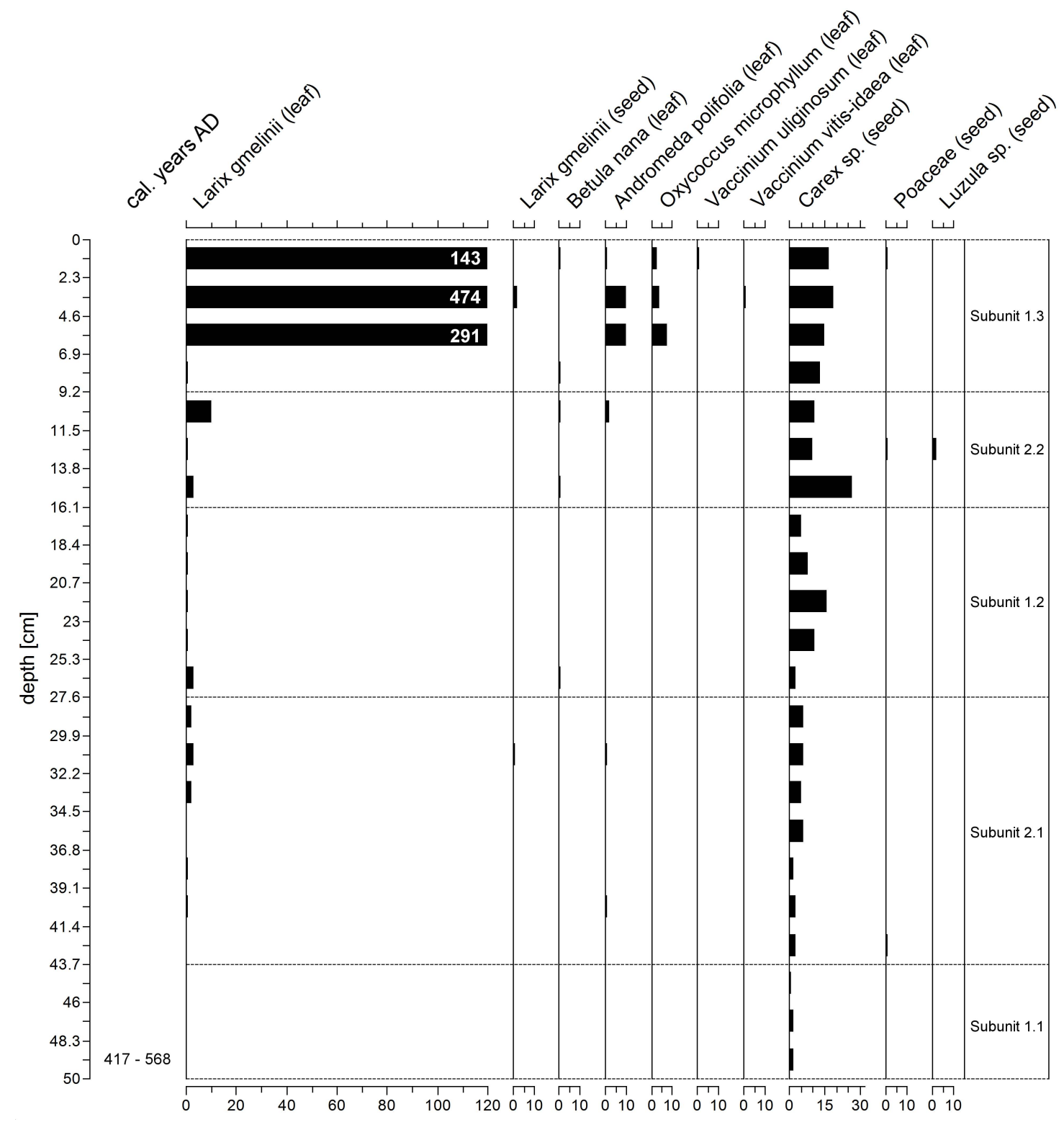

Fig. A6. The macrofossil spectrum for Section B. The peak of Larix leaves in the uppermost samples is due to the presence of trees in the vicinity of the Section B sampling location (see Fig. 3). 


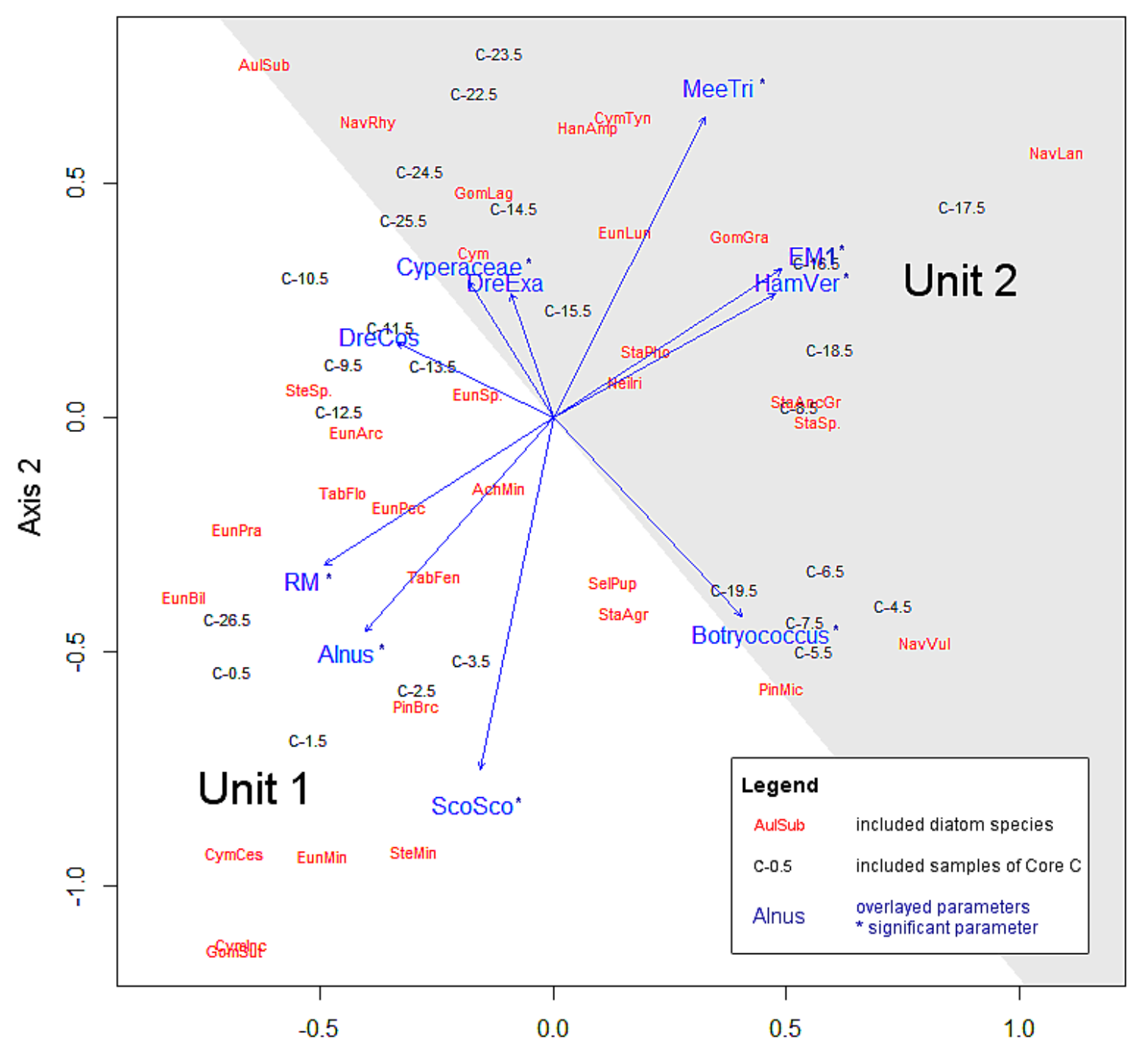

Axis 1

Fig. A7. NMDS plot of the diatom community (excluding the samples at 21.5 and $19.5 \mathrm{~cm}$ length), overlain by the calculated robust endmember (EM1) and the residual member (RM), together with data on important species of moss, pollen, and non-palynomorphs. For abbreviations of diatom species, see Table A1, 
Acknowledgements. The study is a contribution to the joint Russian-German project entitled "Polygons in tundra wetlands: State and dynamics under climate variability in polar regions" (Russian Foundation for Basic Research, RFBR grant no. 11-0491332-NNIO-a, Deutsche Forschungsgemeinschaft, DFG grant no. HE 3622-16-1). We thank all colleagues who helped us during the fieldwork and those who assisted with the analytical work in the geochemical laboratories (Ute Bastian, Antje Eulenburg, Liv Heinecke) and the Stable Isotope Laboratory (Hanno Meyer) at the Alfred Wegener Institute in Potsdam. Furthermore, we thank T. Böhmer for the help with map preparation, M. Wieczorek for support with R graphics, J. Klemm for timely helping with the English genitive and E. Manning for English proofreading.

Edited by: I. Bussmann

\section{References}

Abaimov, A. P.: Geographical Distribution and Genetics of Siberian Larch Species, in Permafrost Ecosystems, vol. 209, edited by: Osawa, A., Zyryanova, O. A., Matsuura, Y., Kajimoto, T., Wein, R. W., Billings, W. D., Golley, F., Lange, O. L., Olson, J. S., and Remmert, H., Springer Netherlands, 41-58, 2010.

Anderberg, A.-L.: Atlas of Seeds: And Small Fruits of NorthwestEuropean Plant Species with Morphological Descriptions (Sweden, Norway, Denmark, East Fennoscandia, and Iceland), Swedish Natural Science Research Council, Stockholm, 1994.

Andreev, A., Schirrmeister, L., Siegert, C., Bobrov, A. A., Demske, D., Seiffert, M., and Hubberten, H. W.: Paleoenvironmental changes in Northeastern Siberia during the Late Quaternaryevidence from pollen records of the Bykovsky Peninsula, Polarforschung, 70, 13-25, 2002.

Andreev, A. A., Schirrmeister, L., Tarasov, P. E., Ganopolski, A., Brovkin, V., Siegert, C., Wetterich, S., and Hubberten, H.-W.: Vegetation and climate history in the Laptev Sea region (Arctic Siberia) during Late Quaternary inferred from pollen records, Quat. Sci. Rev., 30, 2182-2199, doi:10.1016/j.quascirev.2010.12.026, 2011.

Anon: The diatoms of the USSR, Nauka, Leningrad, 1974.

Anon: The diatoms of the USSR, Nauka, Leningrad, 1988.

Anon: The diatoms of the USSR, Nauka, Leningrad, 1992.

Anon: The diatoms of Russia and adjacent countries (fossil and modern), St. Petersburg University Press, St. Petersburg, 2003.

Beijerinck, W.: Zadenatlas der Nederlandsche Flora ten Behoeve van de Botanie, Palaeontologie, Bodemcultuur en Warenkennis, Veenman, Wageningen, 1947.

Berggren, G.: Atlas of seeds and small fruits of NorthwestEuropean plant species (Sweden, Norway, Denmark, East Fennoscandia and Iceland) with morphological descriptions; Part 2, Cyperaceae, Swedish Natural Science Research Council, Stockholm, 1969.

Berggren, G.: Atlas of seeds and small fruits of northwest-European plant species (Sweden, Norway, Denmark, East Fennoscandia and Iceland) with morphological descriptions: part 3. SalicaceaeCruciferae, Swedish Museum of Natural History, Stockholm, 1981.

Beug, H. J.: Leitfaden der Pollenbestimmung für Mitteleuropa und angrenzende Gebiete (Mit 120 Tafeln, 29 Abbildungen und 13 Tabellen), 1. Auflage, Pfeil, München, 2004.
Birks, H. J. B. and Birks, H. H.: Quaternary Palaeoecology, Edward Arnold, London, 1980.

Blok, D., Heijmans, M. M. P. D., Schaepman-Strub, G., Kononov, A. V., Maximov, T. C., and Berendse, F.: Shrub expansion may reduce summer permafrost thaw in Siberian tundra, Glob. Change Biol., 16, 1296-1305, doi:10.1111/j.13652486.2009.02110.x, 2010.

Boike, J., Wille, C., and Abnizova, A.: Climatology and summer energy and water balance of polygonal tundra in the Lena River Delta, Siberia, J. Geophys. Res., 113, G03025, doi:10.1029/2007JG000540, 2008.

Boike, J., Kattenstroth, B., Abramova, K., Bornemann, N., Chetverova, A., Fedorova, I., Fröb, K., Grigoriev, M., Grüber, M., Kutzbach, L., Langer, M., Minke, M., Muster, S., Piel, K., Pfeiffer, E.-M., Stoof, G., Westermann, S., Wischnewski, K., Wille, C., and Hubberten, H.-W.: Baseline characteristics of climate, permafrost and land cover from a new permafrost observatory in the Lena River Delta, Siberia (1998-2011), Biogeosciences, 10, 2105-2128, doi:10.5194/bg-10-2105-2013, 2013.

Botch, M. S., Kobak, K. I., Vinson, T. S., and Kolchugina, T. P.: Carbon pools and accumulation in peatlands of the former Soviet Union, Global Biogeochem. Cy., 9, 37-46, doi:10.1029/94GB03156, 1995.

Braun-Blanquet, J.: Pflanzensoziologie: Grundzüge der Vegetationskunde, Wien, 1964.

Burn, C. R.: Implications for palaeoenvironmental reconstruction of recent ice-wedge development at Mayo, Yukon territory, Permafrost Periglac., 1, 3-14, doi:10.1002/ppp.3430010103, 1990.

Chernov, Y. I. and Matveyeva, N. V.: Arctic ecosystems in Russia, Ecosystems of the World, 361-508, 1997.

Czudek, T. and Demek, J.: Thermokarst in Siberia and its influence on the development of lowland relief, Quat. Res., 1, 103-120, doi:10.1016/0033-5894(70)90013-X, 1970.

Dam, H. V., Mertens, A., and Sinkeldam, J.: A coded checklist and ecological indicator values of freshwater diatoms from The Netherlands, Netherlands J. Aquat. Ecol., 28, 117-133, doi:10.1007/BF02334251, 1994.

De Klerk, P.: Patterns in vegetation and sedimentation during the Weichselian Late-glacial in north-eastern Germany, J. Biogeogr., 35, 1308-1322, 2008.

De Klerk, P., Donner, N., Karpov, N. S., Minke, M., and Joosten, H.: Short-term dynamics of a low-centred ice-wedge polygon near Chokurdakh (NE Yakutia, NE Siberia) and climate change during the last ca 1250 years, Quat. Sci. Rev., 30, 3013-3031, doi:10.1016/j.quascirev.2011.06.016, 2011.

Dietze, E., Wünnemann, B., Hartmann, K., Diekmann, B., Opitz, S., Paprotzki, M., Runge, M., Yang, S., and Lockot, G.: Windows into the past: On-shore high-stand sediments from lake Donggi Cona, NE Tibetan Plateau, 14, p. 2507, EGU2012-2507, 2012.

Donner, N.: Hydrological windows in low-centered arctic polygons. A landscape ecological perspective on polygon mires, MSc thesis, Greifswald University, 45 pp. + annexes, 2007.

Ellis, C. J. and Rochefort, L.: Century-scale development of polygon-patterned tundra wetland, Bylot Island (73 N, $80 \mathrm{~W}$ ), Ecology, 85, 963-978, 2004.

Epstein, H. E., Raynolds, M. K., Walker, D. A., Bhatt, U. S., Tucker, C. J., and Pinzon, J. E.: Dynamics of aboveground phytomass of the circumpolar Arctic tundra during the past three decades, Environ. Res. Lett., 7, 015506, doi:10.1088/1748-9326/7/1/015506, 
2012.

Farquhar, G. D., Ehleringer, J. R., and Hubick, K. T.: Carbon isotope discrimination and photosynthesis, Annu. Rev. Plant Biol., 40, 503-537, 1989.

Fiedler, S., Wagner, D., Kutzbach, L., and Pfeiffer, E. M.: Element redistribution along hydraulic and redox gradients of lowcentered polygons, Lena Delta, northern Siberia, Soil Sci. Soc. Am. J., 68, 1002-1011, 2004.

Fortier, D. and Allard, M.: Late Holocene syngenetic icewedge polygons development, Bylot Island, Canadian arctic archipelago, Can. J. Earth Sci., 41, 997-1012, 2004.

Frahm, J. P.: Biologie der Moose, Spektrum Akademischer Verlag, Berlin, 2001.

Frahm, J.-P. and Frey, W.: Moosflora, 4, neubearbeitete und erweiterte Auflage, UTB, Stuttgart, 2004.

French, H. M.: The periglacial environment, John Wiley and Sons, New York, 2007.

Harding, R., Kuhry, P., Christensen, T. R., Sykes, M. T., Dankers, R., and Linden, S.: Climate feedbacks at the tundra-taiga interface, Ambio, 12, 47-55, 2002.

Hobbie, S. E., Schimel, J. P., Trumbore, S. E., and Randerson, J. R.: Controls over carbon storage and turnover in high-latitude soils, Glob. Change Biol., 6, 196-210, 2002.

Höfle, S., Rethemeyer, J., Mueller, C. W., and John, S.: Organic matter composition and stabilization in a polygonal tundra soil of the Lena-Delta, Biogeosciences Discuss., 9, 12343-12376, doi:10.5194/bgd-9-12343-2012, 2012.

Hedenäs, L.: Amblystegiaceae - Drepanocladus, Bryophyte Flora of North America, Provisional Publication, Buffalo Museum of Science,USA, available at: http://www.mobot.org/plantscience/ bfna/v2/AmblDrepanocladus.htm (last access: 25 February 2011), 2008.

Huh, Y. and Edmond, J. M.: The fluvial geochemistry of the rivers of Eastern Siberia: III. Tributaries of the Lena and Anabar draining the basement terrain of the Siberian Craton and the TransBaikal Highlands, Geochim. Cosmochim. Ac., 63, 967-987, doi:10.1016/S0016-7037(99)00045-9, 1999.

Isaev, A. P., Protopopov, A. V., Protopopova, V. V., Egorova, A. A., Timofeyev, P. A., Nikolaev, A. N., Shurduk, I. F., Lytkina, L. P., Ermakov, N. B., Nikitina, N. V., Efimova, A. P., Zakharova, V. I., Cherosov, M. M., Nikolin, E. G., Sosina, N. K., Troeva, E. I., Gogoleva, P. A., Kuznetsova, L. V., Pestryakov, B. N., Mironova, S. I., and Sleptsova, N. P.: Vegetation of Yakutia: Elements of Ecology and Plant Sociology, in: The Far North, vol. 3, edited by: Troeva, Isaev, E. I., A. P., Cherosov, M. M., and Karpov, N. S., Springer Netherlands, Dordrecht, 143-260, 2010.

Jäger, E. J.: Rothmaler - Exkursionsflora von Deutschland. Bd. 2: Gefäßpflanzen: Grundband, 19. Aufl. 2005, Spektrum Akademischer Verlag, Berlin, 2005.

Jones, A., Stolbovoy, V., Tarnocai, C., Broll, G., Spaargaren, O., and Montanarella, L.: Soil Atlas of the Northern Circumpolar Region, Europeen Comission, Publications Office of the European Union, Luxembourg, 2010.

Katz, N. J., Katz, S. V., and Kipiani, M. G.: Atlas and Keys of Fruits and Seeds Occuring in the Quaternary Deposits of the USSR, Moscow, 1965.

Kilian, M. R., Van der Plicht, J., and Van Geel, B.: Dating raised bogs: new aspects of AMS 14C wiggle matching, a reservoir effect and climatic change, Quat. Sci. Rev., 14, 959-966, 1995.
Klemm, J., Herzschuh, U., Pisaric, M. F. J., Telford, R., Heim, B., and Pestryakova, L. A.: A pollen-climate transfer function from the tundra and taiga vegetation in Arctic Siberia and its applicability to a Holocene record, Palaeogeogr. Palaeocl., 386, 702713, doi:10.1016/j.palaeo.2013.06.033, 2013.

Komarenko, L. E. and Vasilyeva, I. I.: Prespovodnye diatomovye i sinezelenye vodorosli vodoemov Âkutii, Nauka, Moskva, 1975.

Krammer, K.: Diatoms of Europe, The genus Pinnularia, A.R.G. Gantner Verlag, Königstein, 2000.

Krammer, K.: Diatoms of Europe, The genus Cymbella, A.R.G. Gantner Verlag, Königstein, 2002.

Krammer, K.: Diatoms of Europe, The genera Cymbopleura, Delicata, Navicymbula, Gomphocymbellopsis, Afrocymbella, A.R.G. Gantner Verlag, Königstein, 2003.

Krammer, K. and Lange-Bertalot, H.: Bacillariophyceae, in Süsswasserflora von Mitteleuropa, vol. 2, Gustav Fischer Verlag, Stuttgart/Jena, 1986.

Lange-Bertalot, H.: 85 neue Taxa und über 100 weitere neu definierte Taxa ergänzend zur Süsswasserflora von Mitteleuropa, A.R.G. Gantner Verlag, Stuttgart, 1993.

Lange-Bertalot, H.: Diatoms of Europe, Navicula sensu stricto. 10 Genera separated from Navicula sensu lato. Frustulia, A.R.G. Gantner Verlag, Königstein., 2001.

Lange-Bertalot, H. and Genkal, S. I.: Diatoms from Siberia. I. Islands in the Arctic Ocean (Yugorsky-Shar Strait), Königstein, 1999.

Lange-Bertalot, H. and Metzeltin, D.: Indicators of oligotrophy, Koeltz Scientifc Books, Königstein, 1996.

Lange-Bertalot, H., Metzeltin, D., and Witkowski, A.: Hippodonta gen. nov. Umschreibung und Begründung einer neuen Gattung der Naviculaceae, 1996.

Liebner, S., Zeyer, J., Wagner, D., Schubert, C., Pfeiffer, E.-M., and Knoblauch, C.: Methane oxidation associated with submerged brown mosses reduces methane emissions from Siberian polygonal tundra, J. Ecol., 99, 914-922, doi:10.1111/j.13652745.2011.01823.x, 2011.

Lobin, W., Fischer, E., Frahm, J.-P., Frey, W., and Gams, H.: Kleine Kryptogamenflora, Bd.4, Die Moospflanzen und Farnpflanzen Europas, 6. Aufl., Spektrum Akademischer Verlag, Berlin, 1995.

Longton, R. E.: The role of bryophytes and lichens in polar ecosystems, Special Publication-British Ecological Society, 13, 69-96, 1997.

Loseva, E. I.: Atlas of freshwater Pleistocene diatoms from northeastern Europe, Nauka, St. Petersburg, 2000.

Luthin, J. N. and Guymon, G. L.: Soil moisture-vegetationtemperature relationships in central Alaska, J. Hydrol., 23, 233246, doi:10.1016/0022-1694(74)90005-5, 1974.

Mackay, J. R.: Thermally induced movements in ice-wedge polygons, western arctic coast: a long-term study, Geogr. Phys. Quatern., 54, 41-68, doi:10.7202/004846ar, 2000.

Matveev, I. A. (Ed.): Agricultural Atlas of the Republic Sakha (Yakutia), Nauka, Moscow, 1989.

Matveyeva, N. V.: Floristic classification and ecology of tundra vegetation of the Taymyr Peninsula, northern Siberia, J. Veg. Sci., 5, 813-828, 1994.

Meyer, H.: Studies on recent cryogenesis, in Russian-German Cooperation System Laptev Sea, vol. The expedition LENA 2002, BerPolarforschung und Meeresforschung, Bremerhaven, 29-48, 2003. 
Miller, N. G.: Mosses as Paleoecological Indicators of Lateglacial Terrestrial Environments: Some North American Studies, B. Torrey Bot. Club, 107, 373-391, doi:10.2307/2484158, 1980.

Minke, M., Donner, N., Karpov, N. S., De Klerk, P., and Joosten, H.: Distribution, diversity, development and dynamics of polygon mires: examples from Northeast Yakutia (Siberia), Peatlands Int., 1, 36-40, 2007.

Minke, M., Donner, N., Karpov, N., De Klerk, P., and Joosten, H.: Patterns in vegetation composition, surface height and thaw depth in polygon mires in the Yakutian Arctic (NE Siberia): a microtopographical characterisation of the active layer, Permafrost Periglac., 20, 357-368, 2009.

Moore, J. W.: Benthic algae of southern Baffin Island, IV. Annotated list of Bacillariophyta, Nova Hedwigia, 26, 205-223, 1975.

Moore, P. D., Webb, J. A., and Collinson, M. E.: Pollen analysis, 2nd Edn., Blackwell Science, Oxford, 1991.

Moser, K. A., Korhola, A., Wekcström, J., Blom, T., Pienitz, R., Smol, J. P., Douglas, M. S. V., and Hay, M. B.: Paleohydrology inferred from diatoms in northern latitude regions, J. Paleolimnol., 24, 93-107, doi:10.1023/A:1008173901591, 2000.

Müller, S., Tarasov, P. E., Andreev, A. A., Tütken, T., Gartz, S., and Diekmann, B.: Late Quaternary vegetation and environments in the Verkhoyansk Mountains region (NE Asia) reconstructed from a 50-kyr fossil pollen record from Lake Billyakh, Quat. Sci. Rev., 29, 2071-2086, 2010.

Nebel, M. and Philippi, G.: Die Moose Baden-Württembergs, Ulmer, Stuttgart, 2000.

Oechel, W. C. and Vourlitis, G. L.: The effects of climate charge on land - atmosphere feedbacks in arctic tundra regions, Trend Ecol. Evol., 9, 324-329, doi:10.1016/0169-5347(94)90152-X, 1994.

Oksanen, J., Kindt, R., Legendre, P., O'Hara, B., Stevens, M. H. H., Oksanen, M. J., and Suggests, M.: The vegan package, Community ecology package, available at: http://www.R-project.org (last access: October 2008), 2007.

Ovenden, L.: Peat accumulation in northern wetlands, Quat. Res., 33, 377-386, doi:10.1016/0033-5894(90)90063-Q, 1990.

Palagushkina, O. V., Nazarova, L. B., Wetterich, S., and Schirrmeister, L.: Diatoms of modern bottom sediments in Siberian arctic, Contemp. Probl. Ecol., 5, 413-422, doi:10.1134/S1995425512040105, 2012.

Patrick, R. and Reimer, C. W.: The diatoms of the United States (exclusive of Alaska and Hawaii). Volume 1: Systematic descriptions of diatoms of the taxonomic orders Fragilariales, Eunotiales, Achnanthales, and Navicuales (family Naviculaceae), Monograph 13, The Academy of Natural Sciences, Philadelphia, Pennsylvania, 1966.

Peisker, M.: Modellvorstellungen zur KohlenstoffIsotopendiskriminierung bei der Photosynthese von C 3-und C 4-Pflanzen, Genet. Resour. Crop Ev., 32, 35-65, 1984.

Pestryakova, L. A.: Diatomovye kompleksy ozer Yakutii, Yakutsk State University, Yakutsk, 173 pp., 2008.

Pestryakova, L. A., Herzschuh, U., Wetterich, S., and Ulrich, M.: Present-day variability and Holocene dynamics of permafrostaffected lakes in central Yakutia (Eastern Siberia) inferred from diatom records, Quat. Sci. Rev., 51, 56-70, 2012.

Peterson, K. M. and Billings, W. D.: Tundra Vegetational Patterns and Succession in Relation to Microtopography near Atkasook, Alaska, Arctic Alpine Res., 12, 473, doi:10.2307/1550495, 1980.
Post, W. M., Emanuel, W. R., Zinke, P. J., and Stangenberger, A. G.: Soil carbon pools and world life zones, 298, 156-159, doi:10.1038/298156a0, 1982.

Price, G. D., McKenzie, J. E., Pilcher, J. R., and Hoper, S. T.: Carbon-isotope variation in Sphagnum from hummock-hollow complexes: implications for Holocene climate reconstruction, Holocene, 7, 229-233, doi:10.1177/095968369700700211, 1997.

Reimer, P. J., Baillie, M. G. L., Bard, E., Bayliss, A., Beck, J. W., Bertrand, C. J. H., Blackwell, P. G., Buck, C. E., Burr, G. S., and Cutler, K. B.: IntCal04 terrestrial radiocarbon age calibration, 026 cal kyr BP, Radiocarbon, 46, 1029-1058, 2004.

Riordan, B., Verbyla, D., and McGuire, A. D.: Shrinking ponds in subarctic Alaska based on 1950-2002 remotely sensed images, J. Geophys. Res., 111, G04002, doi:10.1029/2005JG000150, 2006.

Rivas-Martinez, S. and Rivas-Saenz, S.: Worldwide Bioclimatic Classification System, 1996-2009, Phytosciological Research Center, Spain [online] Available from: http://www. globalbioclimatics.org/default.htm (last access: 25 October 2012), 2007.

Romanovsky, N. N.: Distribution of recently active ice and soil wedges in the USSR, in: Field and Theory: Lectures in Geocryology, edited by: Church, M. and Slaymaker, S., University of British Columbia, Canada, 154-165, 1985.

Runkle, B. R. K., Sachs, T., Wille, C., Pfeiffer, E.-M., and Kutzbach, L.: Bulk partitioning the growing season net ecosystem exchange of $\mathrm{CO}_{2}$ in Siberian tundra reveals the seasonality of its carbon sequestration strength, Biogeosciences, 10, 1337-1349, doi:10.5194/bg-10-1337-2013, 2013.

Salonen, J. S., Seppä, H., Väliranta, M., Jones, V. J., Self, A., Heikkilä, M., Kultti, S., and Yang, H.: Holocene thermal maximum and late-Holocene cooling in the tundra of NE European Russia, Quat. Res., 75, 501-511, doi:10.1016/j.yqres.2011.01.007, 2011.

Schilling, N.: Eine isotopenbasierende Analyse an Moosen der nordsibirischen Tundra zur Rekonstruktion der Paläoumwelt über die letzten 1500 Jahren, University of Potsdam, Germany, 2012.

Schirrmeister, L., Grosse, G., Wetterich, S., Overduin, P. P., Strauss, J., Schuur, E. A., and Hubberten, H. W.: Fossil organic matter characteristics in permafrost deposits of the northeast Siberian Arctic, J. Geophys. Res., 116, G00M02, doi:10.1029/2011JG001647, 2011.

Seppä, H. and Birks, H. J. B.: July mean temperature and annual precipitation trends during the Holocene in the Fennoscandian tree-line area: pollen-based climate reconstructions, Holocene, 11, 527-539, doi:10.1191/095968301680223486, 2001.

Shaver, G. R. and Chapin III, F. S.: Production: biomass relationships and element cycling in contrasting arctic vegetation types, Ecol. Monogr., 61, 1-31, 1991.

Tyler, C.: Soil acidity and distribution of species on tussocks and interspaces in schoenus vegetation of South and Southeast Sweden, Plant Ecol., 44, 25-35, doi:10.1007/BF00119798, 1981.

Vanderpuye, A. W., Elvebakk, A., and Nilsen, L.: Plant communities along environmental gradients of high-arctic mires in Sassendalen, Svalbard, J. Veg. Sci., 13, 875-884, doi:10.1111/j.1654-1103.2002.tb02117.x, 2002.

Vitt, D. H.: Patterns of Bryophyte Diversity in Peatlands of Continental Western Canada, Bryologist, 98, 218, 
doi:10.2307/3243306, 1995.

Walker, D. A., Kuss, P., Epstein, H. E., Kade, A. N., Vonlanthen, C. M., Raynolds, M. K., and Daniëls, F. J. .: Vegetation of zonal patterned-ground ecosystems along the North America Arctic bioclimate gradient, Appl. Veg. Sci., 4, 440-463, 2011.

Walling, D. E. and Moorehead, P. W.: The particle size characteristics of fluvial suspended sediment: an overview, Hydrobiologia, 176-177, 125-149, doi:10.1007/BF00026549, 1989.

Weltje, G.: End-member modeling of compositional data: Numerical-statistical algorithms for solving the explicit mixing problem, Math. Geol., 29, 503-549, doi:10.1007/BF02775085, 1997.

Weltje, G. J. and Prins, M. A.: Muddled or mixed? Inferring palaeoclimate from size distributions of deep-sea clastics, Sediment. Geol., 162, 39-62, doi:10.1016/S0037-0738(03)00235-5, 2003.

Wetterich, S., Schirrmeister, L., Meyer, H., Viehberg, F. A., and Mackensen, A.: Arctic freshwater ostracods from modern periglacial environments in the Lena River Delta (Siberian Arctic, Russia): geochemical applications for palaeoenvironmental reconstructions, J. Paleolimnol., 39, 427-449, 2008.

Wolter, J.: Late Holocene development of a polygon mire in NW Yakutia inferred from plant macrofossil and lithological analysis, University of Potsdam, Germany, 2010.
Woo, M.-K. and Guan, X. J.: Hydrological connectivity and seasonal storage change of tundra ponds in a polar oasis environment, Canadian High Arctic, Permafrost Periglac., 17, 309-323, doi:10.1002/ppp.565, 2006.

Yershov, E. D., Kondratyeva, K. A., Zamolotchikova, S. A., Trush, N. I., and Dunaeva Ye, N.: Geocryological map of Russia and neighbouring republics, 1:2,500,000 scale, Moscow State University, Russian Ministry of Geology, edited by: Williams, P. J. and Warren, M. T., (2003). The English language version of the geocryological map of Russia and neighbouring republics (2nd Edn.), A project of Moscow State University, Department of Geocryology, Moscow, 1991.

Yoshikawa, K. and Hinzman, L. D.: Shrinking thermokarst ponds and groundwater dynamics in discontinuous permafrost near Council, Alaska, Permafrost Periglac., 14, 151-160, 2003.

Zoltai, S. C. and Vitt, D. H.: Canadian wetlands: Environmental gradients and classification, Vegetation, 118, 131-137, doi:10.1007/BF00045195, 1995.

Zubrzycki, S., Kutzbach, L., Grosse, G., Desyatkin, A., and Pfeiffer, E.-M.: Organic carbon and total nitrogen stocks in soils of the Lena River Delta, Biogeosciences Discuss., 9, 17263-17311, doi:10.5194/bgd-9-17263-2012, 2012. 